\title{
Relationships between the conditions of cow's milk production and the contents of components of nutritional interest in raw milk farmhouse cheese
}

\author{
Anthony LUCASa,b, Claire AGABRIEL ${ }^{c}$, Bruno MARTIN ${ }^{\mathrm{a}}$, Anne FERLAYa, \\ Isabelle VERDIER-METZ ${ }^{\mathrm{d}}$, Jean-Baptiste COULONa*, Edmond ROCK ${ }^{\mathrm{e}}$ \\ a Unité de Recherches sur les Herbivores, Institut National de la Recherche Agronomique, \\ 63122 Saint-Genès-Champanelle, France \\ b Institut Technique Français des Fromages, 74801 La Roche sur Foron, France \\ c École Nationale d'Ingénieurs des Travaux Agricoles de Clermont-Ferrand, Site de Marmilhat, \\ 63370 Lempdes, France \\ d Unité de Recherches Fromagères, Institut National de la Recherche Agronomique, \\ 15000 Aurillac, France \\ e Unité de Maladies Métaboliques et de Micronutriments, Institut National de la Recherche Agronomique, \\ 63122 Saint-Genès-Champanelle, France
}

Received 16 August 2005 - Accepted 30 November 2005

\begin{abstract}
The aim of this correlational study was to: (1) characterize the composition of cow's milk farmhouse cheeses in terms of average contents and variability in fatty acids, retinol, $\alpha$-tocopherol, folate, $\beta$-carotene, xanthophylls, calcium, phosphorus, magnesium, potassium, zinc, sodium chloride and total antioxidant capacity (TAC) and (2) identify herd characteristics and feeding practices associated with differences in cheese composition. Three hundred and six farmhouse pressed cheeses, produced under real herd management conditions throughout the year, were collected. The conditions of milk production were identified beforehand by means of surveys. The farmhouse cheese was characterized by a high variability in composition. The nature of the basic fodder ration (pasture vs. preserved forages, in particular) explained a great part of the variability in the fat-soluble components in the cheese. The cheese fat was richer in C4:0, C18:0, cis-9 C18:1, trans-11 C18:1, cis-9, trans-11 C18:2 (CLA), $\beta$-carotene, xanthophylls, retinol, $\alpha$-tocopherol and TAC and poorer in C10:0, C14:0 and C16:0 with the pasture-based rations compared with the preservedforage-based rations. In the grazing period, it was the poorest in C6:0 to C14:0, $\beta$-carotene and retinol and the richest in cis-9 C18:1, C18:2 n-6 and C18:3 n-3 with the alpine pasture. It was higher in trans-11 C18:1, CLA, $\beta$-carotene and xanthophylls and lower in C16:0 with a first-use pasture compared with a pasture of higher use rank. A higher percentage of concentrate was associated with higher levels of C14:0 and C16:0 and lower levels of trans-11 C18:1, CLA, C18:2 n-6, C18:3 n-3, xanthophylls and retinol. In the indoor feeding period, the cheese fat was the poorest in trans-11 C18:1, CLA, C18:3 n-3 and $\beta$-carotene with the maize-based rations, while the vitamin A and E supplementation was associated with higher retinol and $\alpha$-tocopherol contents, respectively. Herd characteristics did not markedly affect the cheese composition, except the breed. In particular, Abondance and Montbéliarde breeds were associated with higher CLA percentage in the cheese than the
\end{abstract}

\footnotetext{
* Corresponding author (通讯作者): jbc@clermont.inra.fr
} 
Holstein breed, while the carotenoid content in the cheese was the highest with the Montbéliarde breed and the lowest with the Abondance breed.

cheese / cow's milk / nutritional composition / feeding practices / herd characteristics

摘要 - 农家干酪原料牛奶的生产条件和干酪营养组成之间的关系。本项研究的目的是 (1) 研究牛奶农家干酪的组成特性, 主要针对一些参数的平均水平和变化范围进行研究, 这些 参数包括脂肪酸、维生素 A、 $\alpha$-生育酚、叶酸、 $\beta$-胡萝卜素、叶黄素、钲、磷、镁、钾、 锌、氯化钠、总抗氧化能力 (TAC); 2 确定管理饲养条件与干酪营养成分变化之间的关系。 在选定的地区内收集了 306 份在固有的饲养管理和生产条件下制造的压制干酪。预先对牛 奶的生产条件进行了考察。农家干酪在组成特性上差异非常大。在基础饲料中, 天然饲料 使用的量 (特别是指自然放牧与喂饲色藏饲料的比较) 对干酪中脂溶性化合物的影响非常 大。自然放牧与喂饲败藏饲料相比, 前者生产出的干酪脂肪中丁酸 (C4:0)、硬脂酸 (C18:0), 顺式油酸 (cis-9 C18:1)、反式油酸 (trans-11 C18:1)、共轭亚油酸 (cis-9, trans-11 C18:2, CLA) 含量较高, 脂溶性成分维生素 A、 $\alpha$-生育酚、叶酸、 $\beta$-胡萝卜素、叶黄素含量也较高, 总 抗氧化能力 (TAC) 提高, 但是其脂肪中葵酸 (C10:0)、豆冦酸 (C14:0) 和棕㭣酸 (C16:0) 3 种 饱和脂肪酸的含量较低。在放牧期, 在阿尔卑斯山地区自然放牧的牛奶干酪中 C6:0 至 C14:0 饱和脂肪酸、 $\beta$-胡萝卜素和维生素 $\mathrm{A}$ 的含量最低, 而顺式油酸 (cis-9 C18:1)、亚油酸 (C18:2 n-6) 和亚麻酸 (C18:3 n-3) 这三种不饱和脂肪酸的含量最丰富。将第一次使用和多次使用的牧 场的放牧结果进行了对比，在前者条件下放牧的奶牛生产出的牛奶所加工的干酪中反式油 酸 (trans-11 C18:1)、共轭亚油酸、 $\beta$-胡萝卜素和叶黄素的含量比后者高, 但是棕榈酸 (C16:0) 的含量比后者低。基础饲料中浓缩饲料所占的比例越高, 则相对应的干酪中豆冦酸 (C14:0) 和棕榈酸 (C16:0) 两种饱和脂肪酸的含量高, 而反式油酸 (trans-11 C18:1)、共轭亚油酸 (CLA)、亚油酸 (C18:2 n-6)、亚麻酸 (C18:3 n-3)、叶黄素和维生素 A 含量相对较低。在室内饲 养期间，由于使用玉米基础饲料，干酪脂肪中反式油酸 (trans-11 C18:1)、共轭亚油酸 (CLA), 亚麻酸 $(\mathrm{C} 18: 3 \mathrm{n}-3)$ 和 $\beta$-胡萝卜素的含量最低; 由于饲料中补充了维生素 $\mathrm{A}$ 和维生素 $\mathrm{E}$, 所 以干酪中视黄醇和 $\alpha$-生育酚的含量相对较高。在不考虑奶牛品种特性的前提下，饲养方式 并不能显著影响干酪的营养组成。Abondance 和 Montbéliarde 奶牛比黑白花奶牛牛奶生产 出的干酪中共轭亚油酸 (CLA) 含量高, 用 Montbéliarde 奶牛的奶生产出的干酪中类胡萝卜 素含量最高, 而 Abondance 奶牛的牛奶生产出的干酪中类胡萝卜素含量最低。

干酪 / 奶牛 / 营养组成 / 饲养过程 / 饲养特性

Résumé - Relations entre les conditions de production du lait de vache et les teneurs en composés d'intérêt nutritionnel dans le fromage fermier au lait cru. L'objectif de cette étude corrélationnelle était de : (1) caractériser la composition de fromages fermiers au lait de vache en termes de teneurs moyennes et de variabilité en acides gras, rétinol, $\alpha$-tocophérol, folate, $\beta$-carotène, xanthophylles, calcium, phosphore, magnésium, potassium, zinc, chlorure de sodium et potentiel antioxydant total (TAC), et (2) identifier les caractéristiques du troupeau et les pratiques alimentaires associées à des différences de composition du fromage. Trois cent six fromages fermiers à pâte pressée, produits en conditions réelles tout au long de l'année, ont été prélevés. Les conditions de production du lait ont été préalablement identifiées au moyen d'enquêtes. Le fromage fermier se caractérise par une grande variabilité de composition. La nature de la ration fourragère (pâturage vs. fourrages conservés, en particulier) explique une grande partie de la variabilité en composés liposolubles du fromage. La matière grasse du fromage est plus riche en C4:0, C18:0, C18:1 cis-9, C18:1 trans-11, C18:2 cis-9, trans-11 (CLA), $\beta$-carotène, xanthophylles, rétinol, $\alpha$-tocophérol et TAC et plus pauvre en C10:0, C14:0 et C16:0 avec les rations à base de pâturage comparées aux rations à base de fourrages conservés. En période de pâturage, elle est la plus pauvre en C6:0 à C14:0, en $\beta$-carotène et en rétinol et la plus riche en C18:1 cis-9, C18:2 n-6 et C18:3 n-3 avec un pâturage en alpage. Elle est plus riche en C18:1 trans-11, CLA, $\beta$-carotène et xanthophylles et plus pauvre en C16:0 avec un pâturage de première utilisation comparé à un pâturage d'utilisation de rang supérieur. Un pourcentage plus important de concentré est associé à des niveaux plus importants en C14:0 et C16:0 et plus faibles en C18:1 trans-11, CLA, C18:2 n-6, C18:3 n-3, xanthophylles et rétinol. En hiver, la matière grasse du fromage est la plus pauvre en C18:1 trans-11, CLA, $\mathrm{C} 18: 3$ n-3 et $\beta$-carotène avec les rations à base de maïs, tandis que la supplémentation en vitamines A et $E$ est associée à des niveaux plus importants de rétinol et d' $\alpha$-tocophérol, respectivement. Les caractéristiques du troupeau ont peu d'incidence sur la composition du fromage excepté la race. 
En particulier, les races Abondance et Montbéliarde sont associées à un pourcentage en CLA plus élevé dans le fromage que la race Holstein, alors que la teneur en caroténoïdes du fromage est la plus élevée avec la race Montbéliarde et la plus faible avec la race Abondance.

fromage / lait de vache / composition nutritionnelle / pratiques alimentaires / caractéristiques du troupeau

\section{INTRODUCTION}

Reliable and sufficiently detailed food composition data are essential for food and nutrition science, dietetics, food manufacturing and labeling, ensuring food quality and safety and consumer education [27]. Unfortunately, the food composition databases are currently inadequate. Much of the food composition information used worldwide is insufficiently reliable and accurate because it is based on outmoded technology and on analytical techniques that have been improved since the data were collected years ago. Moreover, the representativeness of these data is often questionable considering the low number of analytical samples from which result certain average values when this information is known. For the same reason, the variability inherent in a food is currently likely to be underestimated in many cases. In addition, the lack of accuracy in description of the food composition in most of the databases mainly results from the lack of knowledge of the influence of the production factors on the nutritional characteristics of foods [27].

Within the Western diet, cheese represents a large part of the total dairy product consumption, in particular in countries such as France, Greece or Italy [12] and in higher socioeconomic classes [64]. Owing to its high macronutrient and micronutrient contents, this dairy product is therefore likely to have some influence on the consumer's health $[19,47]$. Generally, the macronutrient contents in cheese are relatively well known and handled owing to their important role in organoleptic and technological properties [25]. On the other hand, its fine composition in components of nutritional interest such as fatty acids (FA), vitamins, minerals, trace elements and antioxidant compounds is affected by the lack of available reliable and accurate data, in particular due to the great number of factors likely to influence it. Firstly, the composition of the original milk from which cheese is manufactured can vary according to nutritional, genetic and physiological factors. The botanical composition, maturity stage and preservation mode of forages fed to the ruminants are factors known to influence the milk composition in FA, vitamins and carotenoids [14, 29]. Similarly, the FA profile of milk greatly depends on the nature and quantity of concentrate in the diet [13]. In addition, mineral and vitamin supplementations increase the contents of certain of these micronutrients in milk $[28,29]$. Besides the dietary factors, the nutritional composition of milk also depends on the species, breed, parity, milk yield and stage of lactation of the animals [28, 29, 36, 59]. Secondly, during the cheese-making process, the composition of the original milk is modified differently depending on the process. For example, the mineral composition of cheese greatly varies according to the rate of acid production and the $\mathrm{pH}$ of whey at draining [49], while its content of vitamin B mainly depends on the level of microbial synthesis [61].

While the main factors influencing the nutritional composition of cheese seem broadly identified, their relative influence on the nutritional characteristics of cheeses produced under real production conditions in coherent production systems is currently poorly known. In a previous study [48], we showed that the cheese composition in FA, carotenoids and $\alpha$-tocopherol, as well as to a lesser extent in retinol, mainly depends on the milk composition and consequently on the conditions of milk production. Similarly, the total antioxidant capacity (TAC) in cheese could also be influenced by the conditions of milk production. In contrast, the variations in mineral and folate contents in cheese are almost exclusively caused by 
the cheese-making process. The following step thus consists of considering the influence of the different conditions of milk production on the nutritional composition of cheese, focusing on the components likely to vary in cheese according to these parameters, i.e. FA, carotenoids, retinol, $\alpha$-tocopherol and TAC.

In this context, the aim of this study was to: (1) characterize the nutritional composition of cow's milk farmhouse cheese in terms of average contents and variability in a large range of components of nutritional interest (FA, retinol, $\alpha$-tocopherol, folate, $\beta$-carotene, xanthophylls, calcium, phosphorus, magnesium, potassium, zinc, sodium chloride and TAC), and (2) specify the role of the management practices in this variability in composition.

\section{MATERIALS AND METHODS}

\subsection{Study design}

This work was a correlational study conducted between August 2002 and December 2004 in two French mountain areas, i.e. Northern Alps and Massif Central. It was carried out under real herd management conditions to study a large range of conditions of milk production and on the scale of the farm in order to be able to link the cheese characteristics with the conditions of milk production. Three French farmhouse cow's raw milk cheese varieties were studied: Abondance cheese (pressed semi-cooked cheese) and Tomme de Savoie cheese (pressed uncooked cheese) in the Northern Alps area, and Cantal-type cheese (pressed uncooked cheese) in the Massif Central area. The main characteristics of these cheeses have been previously described [48]. In total, 54 farms were sampled by the producer trade unions of these cheeses so as to have a farm sample representing the existing broadness of the conditions of milk production. Cheese samples were obtained directly from the farmhouse producers, except 24 Cantal-type cheeses which were manufactured in an experimental dairy from milk collected in different farms. For each cheese variety, the collected samples were produced at 6 periods of the year, including 2 in the indoor feeding period when the cows received a diet based on preserved forages, and 4 throughout the grazing period. In total, 306 cheeses were collected.

\subsection{Data collection}

A first general survey was done in order to characterize the farms and validate the diversity of the production systems among the selected farmhouse producers. Questions were asked about (1) farm characteristics (altitude, area and milking material); (2) herd characteristics (dairy cow number, breed, age, parity and calving distribution); (3) milk production; (4) cheese production; (5) forage management (forage characteristics, cutting and grazing periods, and fertilization); and (6) herd feeding (types of feed). The main characteristics of the three groups of farms are presented in Table I.

Thereafter, a survey was carried out on the day of manufacturing of each collected cheese directly at the farm. The collected data were related either to herd characteristics (milk yield, breed, calving distribution and percentage of primiparous) or to herd feeding (forage, concentrate and vitamin and mineral supplementations). Special attention was paid to: (1) characteristics of forages, i.e. type of forage (maize or grass), type of grassland (highland, permanent grassland or temporary grassland), preservation mode (pasture, hay, silage or wrapped forages), use rank of the grass (first use or higher use rank); (2) composition of concentrates; (3) composition of supplements (vitamins $\mathrm{A}$ and $\mathrm{E}, \mathrm{Ca}, \mathrm{P}, \mathrm{Mg}, \mathrm{K}$ and $\mathrm{Zn}$ ); and (4) estimated levels of each one of these feeds fed to the herd.

\subsection{Cheese collection and analyses}

Cheese samples were collected and freeze-dried as previously described by Lucas et al. [48]. Dry matter and fat contents in the cheese were determined using the AFNOR method [1] and the Heiss butyrometric method [30], respectively. Sodium chloride $(\mathrm{NaCl})$ content was measured using a chloride analyzer (Model 926, 
Table I. Characteristics of the three farm groups.

\begin{tabular}{|c|c|c|c|}
\hline & Abondance & Tomme de Savoie & Cantal-type \\
\hline $\begin{array}{l}\text { Herd number } \\
\text { Area }\end{array}$ & 16 & 18 & 20 \\
\hline Farm altitude (m) & $973 \pm 165$ & $674 \pm 249$ & $827 \pm 165$ \\
\hline Usable farm area (ha) & $94 \pm 44$ & $111 \pm 84$ & $119 \pm 61$ \\
\hline Dairy main fodder $\operatorname{area}^{1}$ (ha) & $70 \pm 38$ & $80 \pm 51$ & $75 \pm 51$ \\
\hline \multicolumn{4}{|l|}{ Fodder area (number of herds) } \\
\hline Highland pasture & 9 & 6 & 3 \\
\hline Permanent grassland & 16 & 17 & 20 \\
\hline Temporary grassland & 3 & 8 & 7 \\
\hline Other fodder crops ${ }^{2}$ & 1 & 6 & 5 \\
\hline \multicolumn{4}{|l|}{ Herds } \\
\hline Dairy cow number & $40 \pm 13$ & $56 \pm 36$ & $55 \pm 26$ \\
\hline Percentage of primiparous (\%) & $28 \pm 8.2$ & $28 \pm 12$ & $21 \pm 7.4$ \\
\hline Milk yield $\left(\mathrm{L} \cdot \mathrm{cow}^{-1} \cdot\right.$ year $\left.^{-1}\right)$ & $5690 \pm 1300$ & $4948 \pm 1607$ & $4548 \pm 1157$ \\
\hline \multicolumn{4}{|l|}{ Breed $^{3}$ (number of herds) } \\
\hline Abondance & 10 & 4 & 0 \\
\hline Montbéliarde & 5 & 3 & 13 \\
\hline Holstein & 0 & 3 & 3 \\
\hline Other breeds and breed mix & 1 & 8 & 4 \\
\hline \multicolumn{4}{|l|}{ Calving period $\mathbf{4}$ (number of herds) } \\
\hline Winter (January - February - March) & 0 & 2 & 8 \\
\hline Spring (April - May - June) & 0 & 0 & 7 \\
\hline Summer (July - August - September) & 1 & 3 & 2 \\
\hline Autumn (October - November - December) & 12 & 5 & 0 \\
\hline Distributed & 3 & 8 & 3 \\
\hline \multicolumn{4}{|l|}{ Dairy cow's feeding } \\
\hline \multicolumn{4}{|l|}{ Winter feeding } \\
\hline \multicolumn{4}{|l|}{ Forages fed (number of herds) } \\
\hline Hay & 16 & 17 & 5 \\
\hline Hay + maize silage & 0 & 1 & 5 \\
\hline Hay + fermented grass & 0 & 0 & 10 \\
\hline Concentrates distributed $\left(\mathrm{kg} \cdot \mathrm{cow}^{-1} \cdot \mathrm{day}^{-1}\right)$ & $6.3 \pm 1.9$ & $4.6 \pm 2.3$ & $5.1 \pm 2.0$ \\
\hline MVS $^{5}$ distributed daily (number of herds) & 16 & 15 & 17 \\
\hline \multicolumn{4}{|l|}{ Summer feeding } \\
\hline Pasture-based ration (number of herds) & 16 & 18 & 20 \\
\hline \multicolumn{4}{|l|}{ Fodder supplementation (number of herds) } \\
\hline Hay & 9 & 17 & 19 \\
\hline Green maize fodder & 2 & 5 & 0 \\
\hline Concentrates distributed $\left(\mathrm{kg} \cdot \mathrm{cow}^{-1} \cdot \mathrm{day}^{-1}\right)$ & $3.9 \pm 1.8$ & $3.1 \pm 1.8$ & $3.5 \pm 1.3$ \\
\hline MVS $^{5}$ distributed daily (number of herds) & 9 & 14 & 17 \\
\hline
\end{tabular}

${ }^{1}$ Area exclusively used for the feeding of the dairy cows in production. ${ }^{2}$ Maize, beet or sorghum.

$3 \mathrm{~A}$ herd was considered as a breed mix when the percentage of cows of the dominant breed represented less than $70 \%$ of the total number of cows. ${ }^{4}$ The distribution of calving of a herd was considered as distributed when the number of cows calving during the dominant calving period represented less than $40 \%$ of the total calving number of the year. ${ }^{5}$ MVS: mineral-vitamin supplements. 
Corning, Halstead, Essex, United Kingdom). The fatty acid (FA) profile was analyzed by gas chromatography after transesterification of FA to FA methyl esters [45]. Retinol (vitamin A), $\alpha$-tocopherol (vitamin E), $\beta$-carotene and xanthophyll (lutein and zeaxanthin) contents were simultaneously measured by HPLC using an UV-visible photodiode-array detector after saponification and hexane extraction, adapted from Lyan et al. [50] as previously described [48]. Folate (vitamin B9) content was determined by microbiological assay using Lactobacillus rhamnosus [15] following an extraction performed by trienzyme treatment [56]. Calcium $(\mathrm{Ca})$, magnesium $(\mathrm{Mg})$ and zinc $(\mathrm{Zn})$ contents were determined by atomic absorption spectrophotometry, potassium $(\mathrm{K})$ content by atomic emission spectrophotometry [46] and phosphorus $(\mathrm{P})$ content by a colorimetric method [2]. The total antioxidant capacity (TAC) was assessed using the ferric reducing/antioxidant power (FRAP) assay adapted from Benzie and Strain [7] as previously described by Lucas et al. [48].

\subsection{Data analysis}

In a previous work [48], we showed that apart from the aspects related to the dry matter content, the FA, carotenoid, retinol, $\alpha$-tocopherol and TAC levels in cheese did not depend on the type of cheese-making technology. Consequently, the composition databases of the three studied cheese varieties were pooled after adjustment for the fat content for fat-soluble components or for the dry matter content for TAC.

The general analytical principles used to establish the relationships between the conditions of milk production and the nutritional characteristics of the cheese were based on those described by Dohoo et al. [23]. First, the number of explanatory variables was reduced by performing synthetic variables and each quantitative variable was categorized prior to investigating associations with cheese composition. Nine categorical explanatory variables were performed: (1) nature of the basic fodder ration; (2) percentage of concentrate in the herd diet; (3) percentage of fat from concentrate in the herd diet, (4) level of vitamin A supplementation; and (5) level of vitamin E supplementation as nutritional factors; (6) herd breed as a genetic factor; (7) herd lactation stage; and (8) percentage of primiparous in the herd as physiological factors; and (9) herd milk yield. The modalities of these different predictor variables are described in Table II. The variable concerning the nature of the basic fodder ration was performed after summarization of the information about the different characteristics of forages (type of forage, type of grassland, preservation mode and use rank of the grass). The data about the percentage of concentrate, percentage of fat from concentrate, level of vitamin A supplementation, level of vitamin E supplementation, milk yield and percentage of primiparous were only categorized to perform the corresponding explanatory variables. The fat content of concentrates and the vitamin contents of supplements were obtained from the commercial labels. The variable for breed was established by regrouping the cheeses resulting from milk of herds with the same dominant breed, considering a breed as dominant when it represented more than $70 \%$ of the total number of cows. To classify the cheeses according to the herd lactation stage we considered the average lactation stage of the herd and the percentage of cows in early lactation ( $<2$ months) and in late lactation ( $>7$ months). Finally, each quantitative dependent variable was categorized into two clusters with a view to multiple correspondence analysis (MCA).

Subsequently, an overview of the complex relationships between and among the dependent and explanatory variables was established using MCA. Pearson correlations were initially undertaken between the FA, $\beta$-carotene, xanthophylls, retinol, $\alpha$-tocopherol and TAC. The linearity of the relationship was graphically checked. MCA was performed using Statistica 6.1 software (Statsoft Inc., Maison-Alfort, France). To describe in an optimum way simultaneously the vitamin and carotenoid contents and the FA profile of the cheese, only some of the components were used to construct the factorial axes. These components were 
Table II. Categorical variables describing management practices.

\begin{tabular}{|c|c|c|c|}
\hline Variable label & Level & $n^{1}$ & Abbr. $^{2}$ \\
\hline \multirow[t]{11}{*}{ Basic fodder ration } & Alpine pasture (100\%) including high percentage of first-use grass (89\%) & 23 & PA1 \\
\hline & First-use permanent grassland pasture $(100 \%)$ & 15 & PP1 \\
\hline & Second or more use permanent grassland pasture (100\%) & 31 & PP2 \\
\hline & First-use permanent grassland pasture ( $78 \%$ ) with hay supplementation $(22 \%)$ & 32 & $\mathrm{PP} 1 / \mathrm{H}$ \\
\hline & $\begin{array}{l}\text { Second or more use permanent grassland pasture (69\%) with hay } \\
\text { supplementation }(31 \%)\end{array}$ & 91 & $\mathrm{PP} 2 / \mathrm{H}$ \\
\hline & Temporary grassland pasture (60\%) with hay supplementation $(25 \%)$ & 17 & $\mathrm{PT} / \mathrm{H}$ \\
\hline & High percentage of fermented grass-based forages $(61 \%)$ & 12 & Ferm \\
\hline & First-cut permanent grassland hay $(72 \%)$ & 36 & HP1 \\
\hline & High percentage of second-cut permanent grassland hay $(54 \%)$ & 32 & HP2 \\
\hline & High percentage of temporary grassland hay $(40 \%)$ & 8 & HT \\
\hline & High percentage of maize-based forages $(54 \%)$ & 9 & Maize \\
\hline \multirow{3}{*}{$\begin{array}{l}\text { Percentage of } \\
\text { concentrate }\end{array}$} & Low percentage in the herd diet $(15 \%)$ & 114 & Cc- \\
\hline & Medium percentage in the herd diet $(26 \%)$ & 104 & $\mathrm{Cc}=$ \\
\hline & High percentage in the herd diet $(41 \%)$ & 88 & $\mathrm{Cc}+$ \\
\hline \multirow{3}{*}{$\begin{array}{l}\text { Percentage of fat } \\
\text { from concentrate }\end{array}$} & Low percentage in the herd diet $(0.32 \%)$ & 93 & Fat- \\
\hline & Medium percentage in the herd diet $(0.62 \%)$ & 133 & Fat $=$ \\
\hline & High percentage in the herd diet $(1.1 \%)$ & 80 & Fat+ \\
\hline \multirow{5}{*}{$\begin{array}{l}\text { Level of vitamin A } \\
\text { supplementation }\end{array}$} & None & 52 & VA0 \\
\hline & Low daily supplementation (29000 IU.cow ${ }^{-1}$ ) & 81 & VA- \\
\hline & Medium daily supplementation (76000 IU.cow ${ }^{-1}$ ) & 68 & $\mathrm{VA}=$ \\
\hline & High daily supplementation (157000 IU.cow ${ }^{-1}$ ) & 47 & $\mathrm{VA}+$ \\
\hline & Unknown & 58 & - \\
\hline \multirow{5}{*}{$\begin{array}{l}\text { Level of vitamin E } \\
\text { supplementation }\end{array}$} & None & 56 & VE0 \\
\hline & Low daily supplementation $\left(50 \mathrm{IU} \cdot \mathrm{cow}^{-1}\right)$ & 109 & VE- \\
\hline & Medium daily supplementation (160 IU $\cdot \operatorname{cow}^{-1}$ ) & 52 & $\mathrm{VE}=$ \\
\hline & High daily supplementation (350 IU.cow ${ }^{-1}$ ) & 31 & $\mathrm{VE}+$ \\
\hline & Unknown & 58 & - \\
\hline \multirow[t]{4}{*}{ Breed } & Herd of Abondance breed ( $96 \%$ of the herd) & 82 & $\mathrm{Ab}$ \\
\hline & Herd of Montbéliarde breed ( $96 \%$ of the herd) & 137 & Mo \\
\hline & Herd of Holstein breed ( $88 \%$ of the herd) & 38 & Ho \\
\hline & Herd of other breed and breed mix & 49 & - \\
\hline \multirow[t]{4}{*}{ Stage of lactation } & Herd predominantly in early lactation ( 3.3 months, $63 \%$ of cows in early lactation) & 25 & SL- \\
\hline & Herd really in medium lactation (5.3 months, $70 \%$ of cows in medium lactation) & 117 & $\mathrm{SL}=$ \\
\hline & Herd apparently in medium lactation (5.2 months, $38 \%$ of cows in medium lactation) & 82 & - \\
\hline & Herd predominantly in late lactation ( 7.1 months, $58 \%$ of cows in late lactation) & 82 & SL+ \\
\hline \multirow[t]{3}{*}{ Milk yield } & Low level $\left(13.2 \mathrm{~L} \cdot \mathrm{cow}^{-1} \cdot \mathrm{day}^{-1}\right)$ & 92 & MY- \\
\hline & Medium level $\left(18.1 \mathrm{~L} \cdot \operatorname{cow}^{-1} \cdot\right.$ day $\left.^{-1}\right)$ & 138 & $\mathrm{MY}=$ \\
\hline & High level $\left(22.8 \mathrm{~L} \cdot \mathrm{cow}^{-1} \cdot\right.$ day $\left.^{-1}\right)$ & 76 & MY+ \\
\hline \multirow{3}{*}{$\begin{array}{l}\text { Percentage of } \\
\text { primiparous }\end{array}$} & Low percentage ( $8 \%$ of the herd) & 104 & Pri- \\
\hline & Medium percentage ( $23 \%$ of the herd) & 139 & Pri $=$ \\
\hline & High percentage ( $38 \%$ of the herd) & 63 & Pri+ \\
\hline
\end{tabular}

${ }^{1}$ Number of cheeses. ${ }^{2}$ Abbreviation. 
chosen by taking into account both the importance of their nutritional interest and their ability to be good indicators of other components considering the results of the correlation studies. We chose to use the following components to construct the factorial axes of the MCA: the sum of C12:0, C14:0 and C16:0 owing to their important nutritional interest (potential hypercholesterolemic effect) and as good indicators of the other saturated FA (SFA); cis-9 C18:1 as the main unsaturated FA in milk fat; cis-9, trans-11 C18:2 as a good indicator of both polyunsaturated FA (PUFA) and trans $\mathrm{FA}$; and $\beta$-carotene, retinol and $\alpha$-tocopherol owing to their nutritional interest and as good indicators of xanthophylls and TAC. The other dependent variables and the explanatory variables were then plotted onto the projection as illustrative variables.

Finally, the data were analyzed using multivariable ANOVA procedures (Statistica 6.1 software, Statsoft Inc., MaisonAlfort, France). All explanatory variables were initially screened for a simple association with the dependent variables using a univariate ANOVA procedure. Variables that met a critical value of $P \leq 0.25$ upon initial screening were considered in additional multivariate modeling and variables were considered significant at $P \leq 0.05$. A value of $P \leq 0.25$ was used in the initial screening to permit a broad subset of variables to be included in the model-building process. At the same time, this value would eliminate obviously nonassociated variables. Multivariable model building used a forwardselection stepwise procedure with a criterion of $P \leq 0.05$ to remain in the model. Pairwise comparison of least-square means for the various levels of categorical variables was performed. A first analysis showed a strong association between the nature of the basic fodder ration (pasture-based rations vs. preserved-forage-based rations, in particular) and the variations in cheese composition which probably masked the effect of the other predictor variables. Consequently, the effects of the categorical variables were subsequently analyzed within the pasture-based rations and within the preserved-forage-based rations.

\section{RESULTS AND DISCUSSION}

\subsection{Nutritional characteristics of the cheese}

The average composition of the cheeses is shown in Table III. Our data confirmed that cow's milk cheese fat is characterized by an unbalanced FA profile with regard to the human nutritional requirements. Indeed, an excessively high dietary saturated fat to unsaturated fat ratio has been associated with a higher risk of coronary heart diseases [31]. Now, on the basis of a daily consumption of $40 \mathrm{~g}$ of pressed cheese [12], 39\% of the recommended dietary allowances (RDA) for an adult man of SFA and only $3.9 \%, 1.6 \%$ and $4.3 \%$ of the RDA of monounsaturated FA (MUFA), n-6 and n-3 PUFA are on average covered, respectively. Similarly, cheese fat is a significant source of trans FA whose excessive consumption has been associated with a higher risk of coronary arterial diseases [16]. However, it is interesting to note that the contribution of pressed cheese consumption to the maximum recommendations for an adult man in trans FA is about four times lower than its contribution to the RDA in SFA which means that the limiting factor in cheese consumption is more its SFA content than its trans FA content. In contrast, pressed cheeses are interesting sources of some micronutrients. For instance, the consumption of $40 \mathrm{~g}$ of the cheeses studied contributes on average to $35 \%, 27 \%, 13 \%$ and $9.2 \%$ of the RDA of an adult man of $\mathrm{Ca}, \mathrm{P}$, $\mathrm{Zn}$ and vitamin $\mathrm{A}$, respectively. On the other hand, pressed cheeses are relatively poor in $\alpha$-tocopherol, folates and $\mathrm{Mg}$ since only $0.6 \%, 2.5 \%$ and $2.7 \%$ of the RDA of these micronutrients are covered by the consumption of $40 \mathrm{~g}$ of pressed cheese, respectively. Finally, although cheese contains $\mathrm{NaCl}$, of which the consumption in excess has been associated with a high blood pressure [58], the contribution of the consumption of $40 \mathrm{~g}$ of pressed cheese to the maximum recommendations ranged only between $8.5 \%$ and $14 \%$. These results agree with previous findings [6, 24, 68]. Altogether, they show that cheese is a significant source of certain micronutrients, 
but its excessive consumption must be avoided so that it does not unbalance the human diet, in particular its FA profile.

There was, however, a great variability in composition in the cheese (Tab. III). For the fat-soluble components, this variability was partly due to variations in the fat content in the cheese, whose ratio of the 95th centile value to the 5 th centile value (95:5 centile ratio) was on average 1.2. With regard to the $\mathrm{FA}$, the $95: 5$ centile ratio ranged on average from 1.4 for $\mathrm{C} 14: 0$ to 3.9 for cis-9, trans-11 C18:2. Vitamin and carotenoid contents of the cheese also greatly varied since the 95:5 centile ratio was on average 5.6, 3.9, 2.4, 4.6 and 3.6 for $\beta$-carotene, xanthophylls, retinol, $\alpha$-tocopherol and folates, respectively. Similarly, an average 95:5 centile ratio comprising between 1.2 for $\mathrm{P}$ and 2.1 for $\mathrm{NaCl}$ was observed for the minerals. This high variability in the $\mathrm{NaCl}$ content suggests that a better control of salting in the cheese-making process could limit the supply of sodium by the cheese. Finally, with an average $95: 5$ centile ratio of 2.3 , the TAC in the cheese also varied significantly, probably owing to variations in antioxidants such as $\beta$-carotene and $\alpha$-tocopherol, as previously suggested [48]. From a nutritional point of view, this variability is really interesting. For instance, on the basis of a daily consumption of $40 \mathrm{~g}$ of cheese, the contribution of Abondance cheese to the nutritional recommendations for an adult man ranged between the 5 th centile value and the 95th centile value from 36 to $47 \%$ for SFA, from 7.0 to $20 \%$ for trans FA, from 5.5 to $14 \%$ for vitamin $\mathrm{A}$, from 5.9 to $13 \%$ for $\mathrm{NaCl}$ and from 32 to $48 \%$ for Ca, respectively. It is also interesting to note that the potentially hypercholesterolemic FA, i.e. C12:0, C14:0 and C16:0 [31], were subjected to a higher variability than the total SFA, with an average 95:5 centile ratio of 1.4 .

\subsection{Correlation studies}

As regards the nutrients whose level in cheese depends on the conditions of milk production, i.e. FA, carotenoids, retinol, $\alpha$-tocopherol and TAC [48], there were strong correlations between many nutrients in the cheese after adjustment for the fat or dry matter content (Tab. IV), suggesting that they may be influenced by the same factors of production. Hence, the C4:0 was highly positively correlated with C6:0 $(r=$ $0.67)$ and, to a lesser extent, with $C 8: 0$ $(r=0.43)$. Similarly, C6:0, C8:0, C10:0, $\mathrm{C} 12: 0$ and $\mathrm{C} 14: 0$ were strongly positively correlated with each other $(r=0.69$ to 0.96 ) and, to a lesser extent, with $\mathrm{C} 16: 0$ for $\mathrm{C} 10: 0$ $(r=0.35)$ and $\mathrm{C} 14: 0(r=0.47)$ and negatively correlated with $\mathrm{C} 18: 0(r=-0.39$ to $-0.72)$ and cis-9 C18:1 ( $r=-0.65$ to -0.88$)$ and, to a lesser extent, with trans-11 (+trans-10) C18:1, cis-9, cis-12 C18:2, cis-9, trans-11 C18:2 and cis-9, cis-12, cis-15 C18:3 ( $r=-0.22$ to -0.45$)$. Similarly, trans-11 C18:1, cis-9, trans-11 C18:2, $\beta$-carotene, xanthophylls and $\alpha$-tocopherol were strongly positively correlated with each other ( $r=0.40$ to 0.97$)$ and negatively correlated with C16:0 ( $r=-0.47$ to -0.80$)$. Finally, the TAC was positively correlated with the antioxidants, i.e. $\beta$-carotene and $\alpha$-tocopherol ( $r=0.34$ to 0.47$)$. The positive correlations between SFA ranged from $\mathrm{C} 4: 0$ to $\mathrm{C} 16: 0$ are due to the fact that they are synthesized in the mammary gland from the same metabolic pathway [13]. Similarly, the long-chain FA, which arise either from diet or from body fat mobilization, are correlated owing to this common origin [13]. In addition, they have a direct inhibitory effect on the de novo synthesis of the shortand medium-chain FA, hence the negative correlations between these two groups of FA [13].

\subsection{Overview of the relationships between the cheese nutritional characteristics and the manage- ment practices}

The MCA results are shown in Figure 1. The first factorial axis, which explained about half of the total inertia (49.3\%), clearly showed that the cheese was richer in C18:0, cis-9 C18:1, trans-11 (+trans-10) C18:1, conjugated linoleic acid (CLA), C18:3 n-3, xanthophylls, $\beta$-carotene, retinol and $\alpha$-tocopherol and poorer in C6:0 to C16:0 SFA when cows were fed pasturebased rations, low percentages of concentrate 


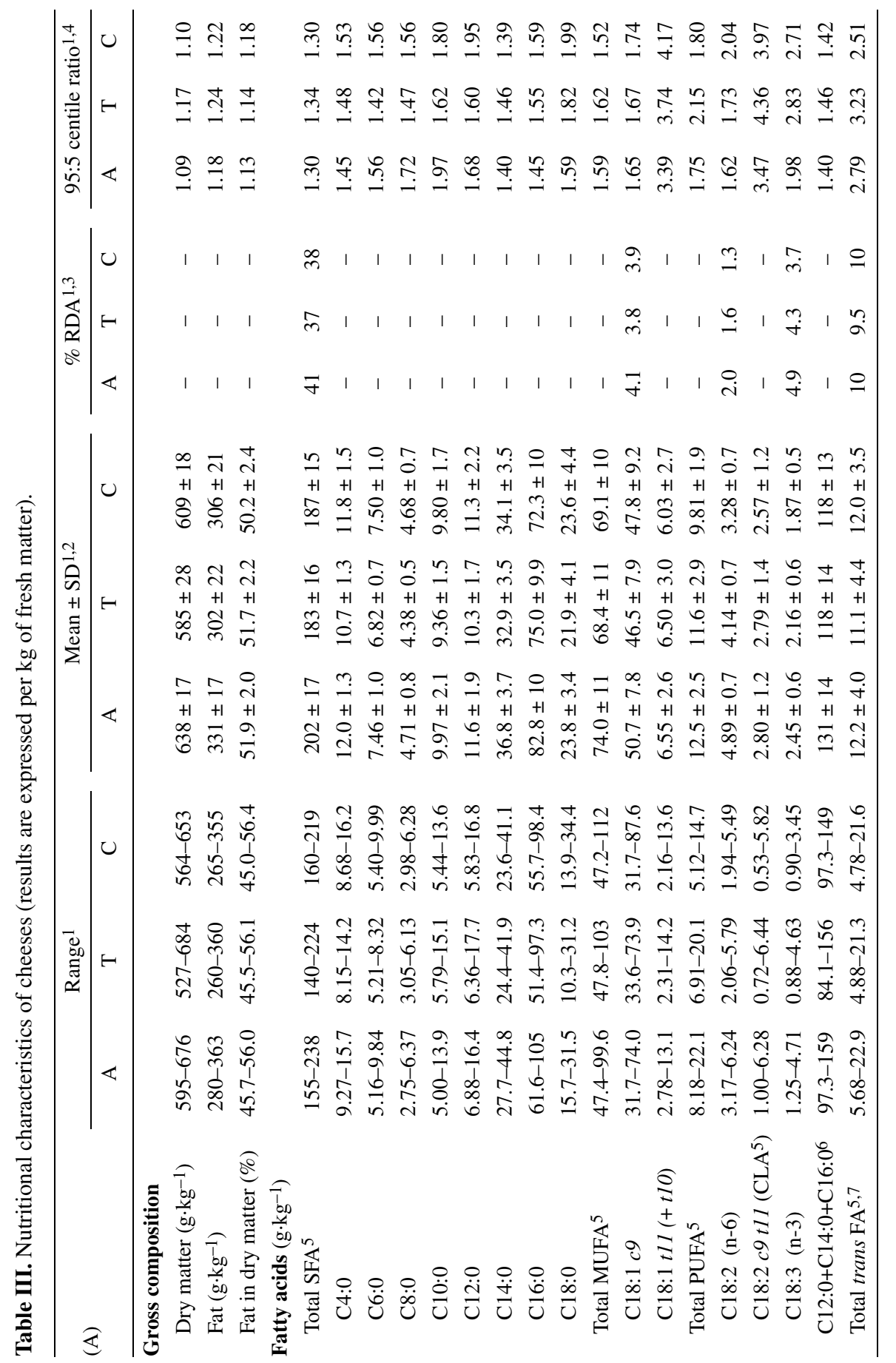




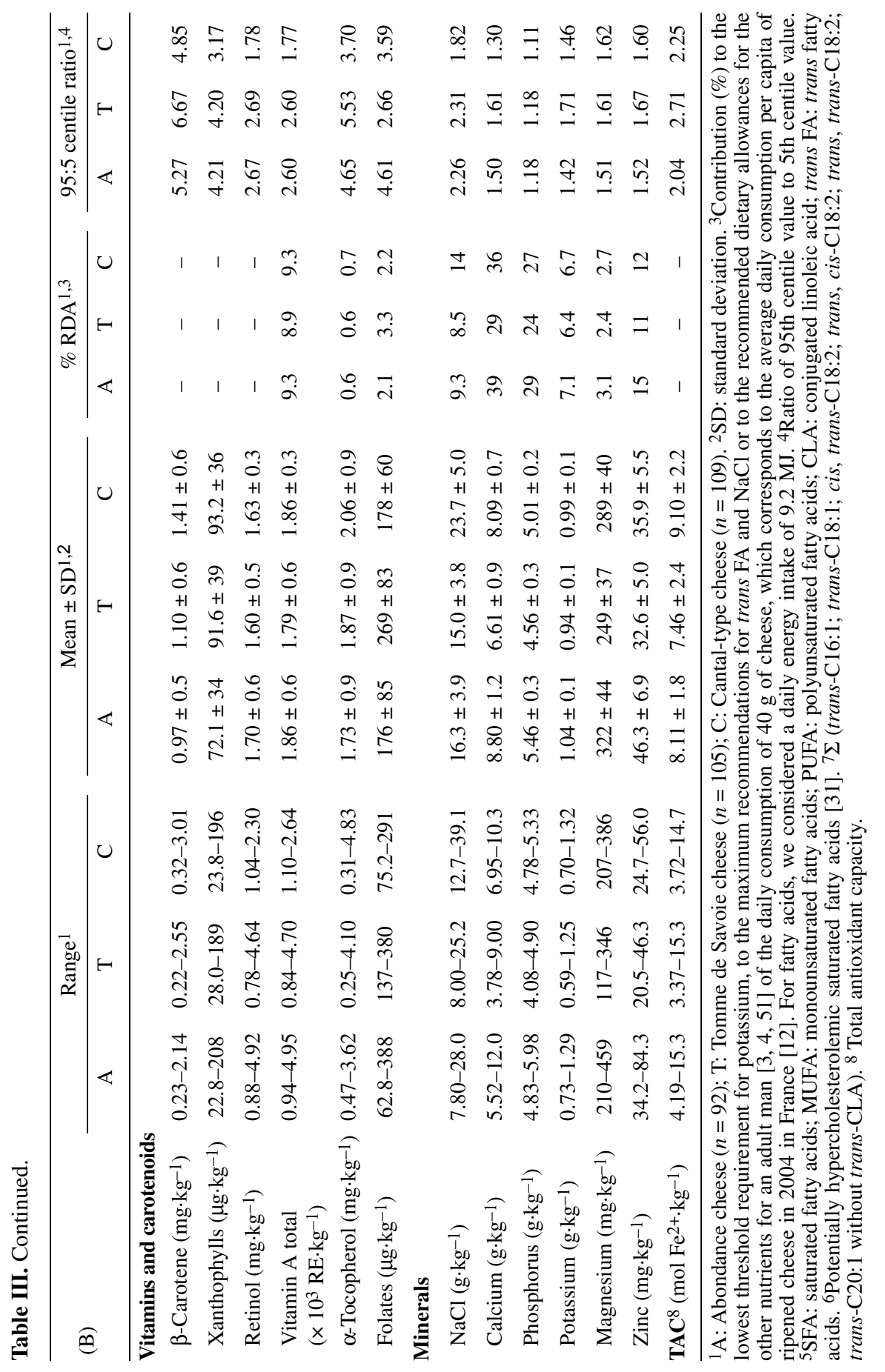




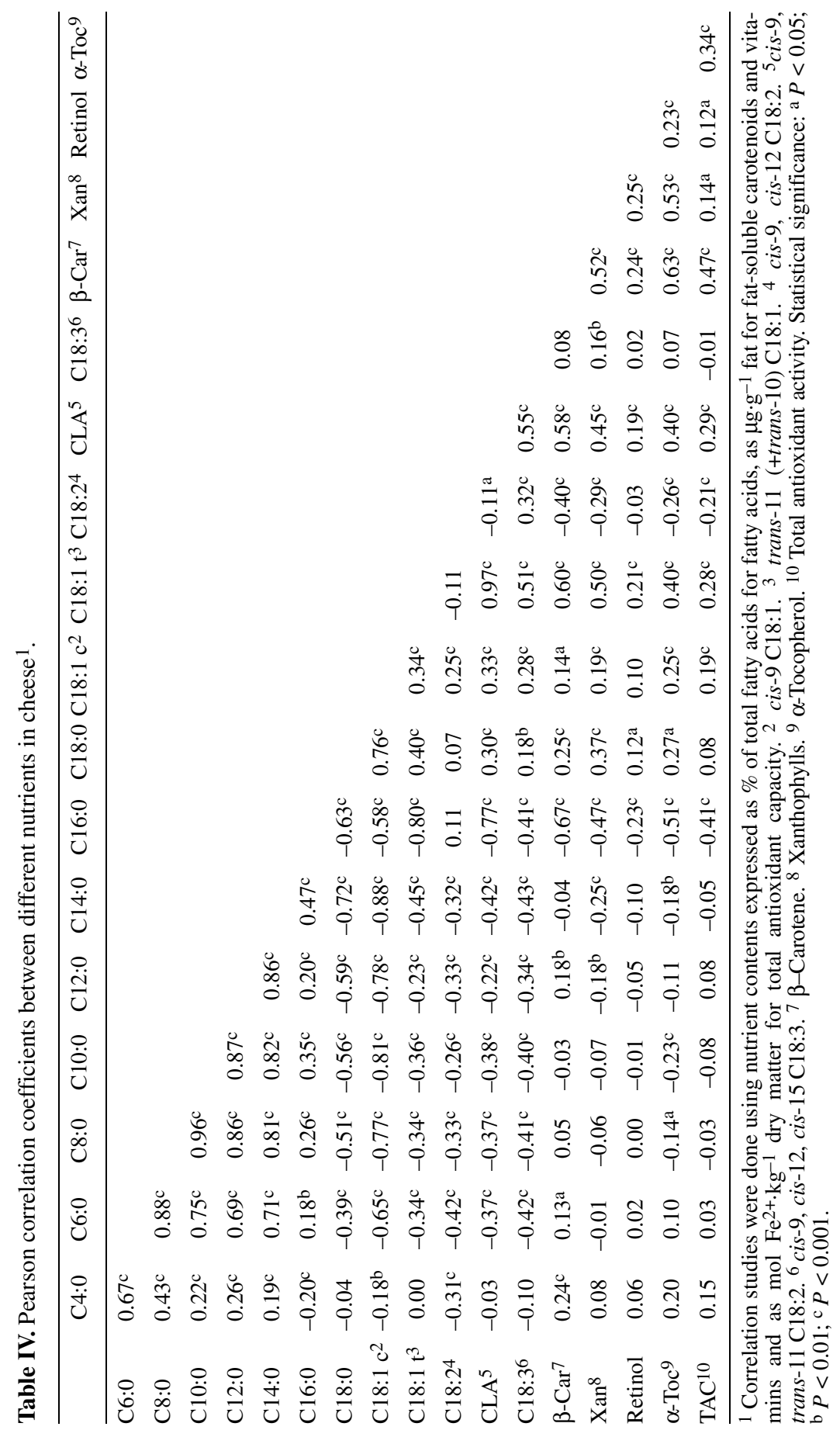




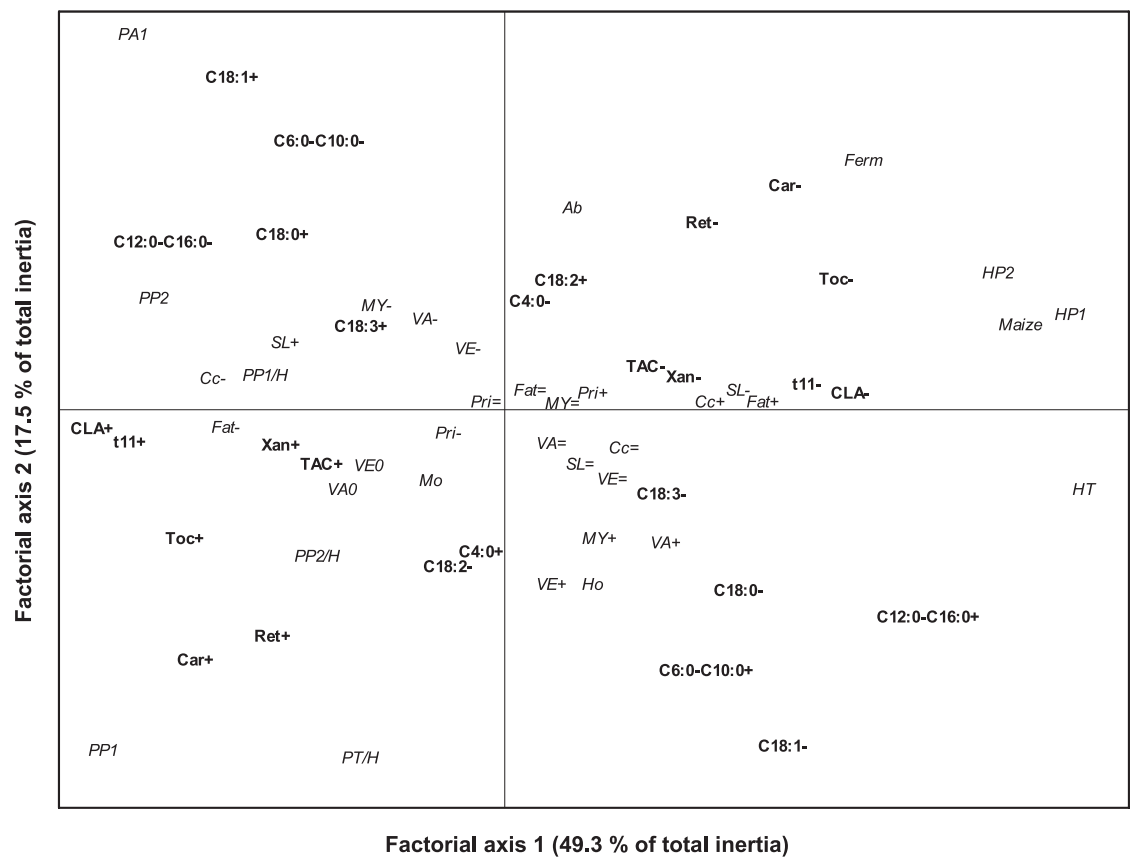

Figure 1. Representation of the relationships between the cheese nutritional characteristics and the management practices using multiple correspondence analysis. Nutritional characteristics (bold characters): C6:0-C10:0: C6:0+C8:0+C10:0; C12:0-C16:0: C12:0+C14:0+C16:0; CLA: cis-9, trans-11 C18:2; t11: trans-11 (+trans-10) C18:1; C18:1: cis-9 C18:1; C18:2: cis-9, cis-12 C18:2; C18:3: cis-9, cis-12, cis-15 C18:3; Xan: xanthophylls; Car: $\beta$-carotene; Ret: retinol; Toc: $\alpha$-tocopherol; TAC: total antioxidant activity; -: low level; +: high level. Management practices (italic characters): see Table II for abbreviations.

and fat from concentrate and were in late lactation than when cows were fed preserved-forage-based rations, high percentages of concentrate and fat from concentrate and were in early lactation. The second axis, which explained $17.5 \%$ of the total inertia, showed that cheese made from milk of herds of the Abondance breed, with a low milk yield and grazing first-use alpine pastures was higher in C18:0, cis-9 C18:1, C18:2 n-6 and C18:3 n-3 and lower in C4:0 to $\mathrm{C} 16: 0$ SFA, $\beta$-carotene, retinol and $\alpha$-tocopherol than cheeses made from milk of herds of the Holstein or Montbéliarde breeds, with a high milk yield and grazing first-use permanent grassland pasture or temporary grassland pasture with a hay supplementation. Finally, it appears that the percentage of primiparous was not clearly related to any specific nutritional characteristics. Similarly, there was no association between the vitamin A and E supplementation and the retinol and $\alpha$-tocopherol contents in cheese.

This overview suggested that the preservation mode of forages (pasture vs. preserved forages) is an important influencing factor of both the FA profile and the fat-soluble micronutrient contents in cheese within the studied range of conditions of milk production. The higher long-chain FA percentages and micronutrient contents in cheese associated with pasture agree with experimental results related to milk [52]. In addition, within the pasture period, it seems that the alpine pasture led to a particular FA profile, 
as already reported $[11,17]$. However, the variations in the cheese composition were also associated with other production factors, which make the interpretation of results difficult. These results illustrate that the management practices are applied within coherent production systems under real conditions of production. Indeed, there are more or less strong associations between the different management practices which can influence synergically or in an opposing way the cheese composition. For example, the variations in the FA profile in cheese according to the preservation mode of forages could be strengthened by the lower percentage of concentrate associated with pasture [22,69], whereas they could be weakened by the earlier stage of lactation associated with preserved forages [13]. In this study, we subsequently attempted to isolate the effect of each production factor on the cheese composition.

\subsection{Effects of the individual manage- ment practices on the nutritional characteristics of cheese}

All the FA, carotenoids, retinol, $\alpha$-tocopherol and TAC levels in cheese were significantly influenced by the conditions of milk production $(P<0.001)$. The statistical model including all the explicative variables explained more than $50 \%$ of the variance of C16:0, trans-11 (+trans-10) C18:1, cis-9, trans-11 C18:2 (CLA), C18:3 n-3, $\beta$-carotene and $\alpha$-tocopherol (Tab. V). The variations in these latter nutrients of cheese were therefore greatly due to the studied conditions of milk production. In contrast, less than $30 \%$ of the variance of $\mathrm{C} 4: 0, \mathrm{C} 6: 0$, C12:0, C14:0, C18:0, cis-9 C18:1, retinol and TAC were explained by this statistical model (Tab. V), which means that the variations in these components greatly depended on unmeasured factors such as the energy balance of cows for FA [13] or the cheese-making process for retinol and TAC [48].

\subsubsection{Basic fodder ration}

Among the different management practices considered in this study, the nature of the basic fodder ration had the strongest influence on most of the nutrients in the cheese (Tab. V). Thus, except for total SFA, total PUFA, C18:2 n-6 and C18:3 n-3, more than $40 \%$ of the variance explained by the full statistical model was due to the nature of the basic fodder ration (Tab. V). The pasture-based rations strongly contrasted with the preserved-forage rations (Tab. VI). Compared with the preservedforage-based rations, the cheese fat was significantly higher in $\mathrm{C} 4: 0, \mathrm{C} 18: 0$, cis-9 C18:1, trans-11 (+trans-10) C18:1, CLA, $\beta$-carotene, xanthophylls, retinol and $\alpha$-tocopherol and lower in C10:0, C14:0 and C16:0 with the pasture-based rations. Similarly, the pasture-based feeding was associated with a higher TAC in the cheese, probably owing to the higher levels of antioxidants ( $\beta$-carotene and $\alpha$-tocopherol). These results agree with previous experimental findings related to milk $[5,52]$. They are explained by a lower supply of total FA, in particular C16:0, C18:2 and C18:3, xanthophylls, $\beta$-carotene and $\alpha$-tocopherol by the preserved forages owing to their oxidative degradation during some operations of the preserved forage-making such as shading, wilting and drying of the grass $[9,20$, $33,62]$. The higher intake of FA from fresh grass brings about a greater formation of C18:0, cis-9 C18:1 and trans-11 C18:1 which result from the ruminal biohydrogenation of dietary $\mathrm{C} 18: 2$ and $\mathrm{C} 18: 3$ and a higher intestinal absorption of these longchain FA. As a result, there are lower percentages of short- and medium-chain FA in milk fat due both to a higher absorption of long-chain FA from the blood by the mammary gland (dilution effect) and to a lower de novo synthesis of FA through a direct inhibitory effect on acetyl-CoA carboxylase [13]. Moreover, since C18:0 and trans-11 C18:1 can be partially desaturated in the mammary gland, the higher absorption of these FA with pasture feeding results in higher percentages of cis-9 C18:1 and cis-9, trans-11 C18:2 in milk, respectively. Similarly, within certain limits, the amount of xanthophylls, $\beta$-carotene, retinol and $\alpha$-tocopherol secreted into milk fat depends directly on their level in the ration [29]. For retinol, it also depends directly on the level 
Table V. Percentage of variance explained by the full statistical model, the error and the nine explanatory variables ${ }^{1}$.

\begin{tabular}{|c|c|c|c|c|c|c|c|c|c|c|c|}
\hline & M & $\mathrm{E}$ & BFR & $\mathrm{PC}$ & PFC & VA & VE & B & SL & MY & PP \\
\hline \multicolumn{12}{|l|}{ Fatty acids } \\
\hline Total SFA ${ }^{2}$ & 57 & 43 & 22 & 2 & - & - & - & 1 & 1 & 1 & - \\
\hline $\mathrm{C} 4: 0$ & 19 & 81 & 17 & - & - & - & - & - & 3 & - & - \\
\hline C6:0 & 22 & 78 & 15 & - & - & - & - & - & 4 & - & - \\
\hline C8:0 & 31 & 69 & 21 & - & - & - & - & - & - & 3 & - \\
\hline C10:0 & 40 & 60 & 24 & - & - & - & - & - & - & 5 & - \\
\hline C12:0 & 24 & 76 & 15 & - & - & - & - & - & - & 5 & - \\
\hline C14:0 & 26 & 74 & 20 & - & - & - & - & - & - & 3 & - \\
\hline C16:0 & 65 & 35 & 60 & - & - & - & - & 4 & - & - & - \\
\hline C18:0 & 25 & 75 & 20 & - & - & - & - & 4 & - & - & - \\
\hline Total MUFA ${ }^{2}$ & 43 & 57 & 37 & - & - & - & - & - & - & 2 & - \\
\hline $\mathrm{C} 18: 1 c 9$ & 24 & 76 & 18 & - & - & - & - & - & - & 2 & - \\
\hline $\mathrm{C} 18: 1 t 11(+t 10)$ & 65 & 35 & 34 & 5 & - & - & - & 3 & - & - & - \\
\hline Total PUFA 2 & 60 & 40 & 17 & 5 & - & - & - & 6 & 1 & 2 & - \\
\hline C18:2 (n-6) & 40 & 60 & 6 & 2 & 4 & - & - & 10 & - & 5 & - \\
\hline $\mathrm{C} 18: 2 c 9 t 11\left(\mathrm{CLA}^{2}\right)$ & 63 & 37 & 30 & 5 & - & - & - & 4 & - & - & - \\
\hline $\mathrm{C} 18: 3(\mathrm{n}-3)$ & 50 & 50 & 17 & 4 & - & - & - & 7 & - & 2 & - \\
\hline $\mathrm{C} 12: 0+\mathrm{C} 14: 0+\mathrm{C} 16: 0^{3}$ & 56 & 44 & 31 & 1 & - & - & - & 2 & - & 1 & - \\
\hline Total trans $\mathrm{FA}^{2,4}$ & 66 & 34 & 33 & 5 & - & - & - & 3 & - & - & - \\
\hline \multicolumn{12}{|l|}{ Vitamins and carotenoids } \\
\hline$\beta$-Carotene & 68 & 32 & 54 & - & - & - & - & 8 & - & - & - \\
\hline Xanthophylls & 37 & 63 & 16 & 2 & - & - & - & 8 & - & - & - \\
\hline Retinol & 16 & 84 & 14 & - & - & 3 & - & - & - & - & - \\
\hline$\alpha$-Tocopherol & 50 & 50 & 44 & - & - & - & - & - & - & 2 & - \\
\hline TAC $^{5}$ & 25 & 75 & 25 & - & - & - & - & - & - & - & - \\
\hline
\end{tabular}

${ }^{1} \mathrm{M}$ : full statistical model; E: error; BFR: type of basic fodder ration; PC: percentage of concentrate in the herd diet; PFC: percentage of fat from the concentrate in the herd diet; VA: level of vitamin A supplementation; VE: level of vitamin E supplementation; B: herd breed; SL: herd lactation stage; MY: herd milk yield; PP: percentage of primiparous in the herd. ${ }^{2}$ SFA: saturated fatty acids; MUFA: monounsaturated fatty acids; PUFA: polyunsaturated fatty acids; CLA: conjugated linoleic acid; trans FA: trans fatty acids. ${ }^{3}$ Potentially hypercholesterolemic saturated fatty acids [31]. ${ }^{4} \Sigma$ (trans-C16:1; trans-C18:1; cis, trans-C18:2; trans, cis-C18:2; trans, trans-C18:2; trans-C20:1 without trans-CLA). ${ }^{5}$ TAC: total antioxidant capacity.

of provitamin A in the forages, in particular $\beta$-carotene, which is partially converted into vitamin A in the wall of the small intestine [29]. Thus, a higher intake of these micronutrients from fresh grass brings about a greater secretion into milk.

\subsubsection{Pasture-based rations}

Within the grazing period, the cheeses resulting from cows fed a fodder ration made up exclusively of alpine pasture significantly differed from the other cheeses as 


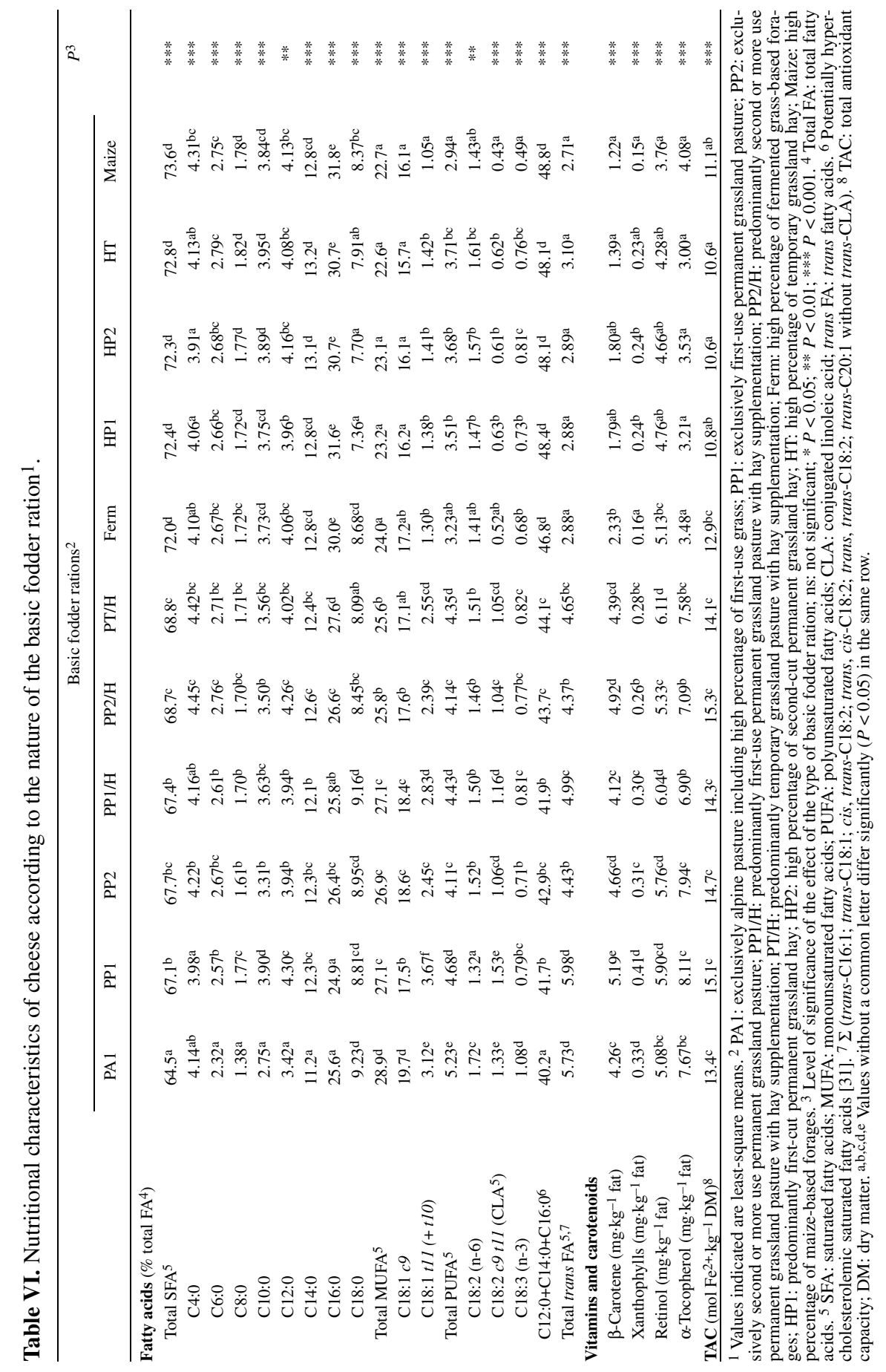


regards the FA profile (Tab. VI), in agreement with previous studies $[11,17]$. They were the richest in cis-9 C18:1, C18:2 n-6 and $\mathrm{C} 18: 3 \mathrm{n}-3$ and the poorest in C6:0 to C14:0. In addition, the cheese fat was significantly poorer in $\beta$-carotene and also tended to be poorer in retinol $(P=0.09)$ with the first-use alpine pasture than with the first-use permanent grassland pasture (Tab. VI). Variations in the botanical composition of grasslands according to their altitude $[10,35]$ and differences in FA and carotenoid contents in pasture between the grass species $[9,21,38,60]$ could have led to differences in FA and carotenoid intake by the cows. The harsher conditions of grazing in highland pastures than in middle mountain grasslands could also partially explain the observed differences in FA composition according to the pasture altitude. Indeed, both the relatively low environmental temperatures and the increased physical activity for the search of food on alpine pastures could lead to a negative energy balance in the cows $[8,63]$ resulting in a greater amount of long-chain FA (predominantly $\mathrm{C} 18: 0$ and cis-9 $\mathrm{C} 18: 1)$ taken up from the plasma by the mammary gland due to body fat mobilization [13], as previously suggested by Bugaud et al. [11]. The lower milk yield of cows grazing in alpine pastures compared with that of cows grazing in other pastures (13.6 vs. $17.9 \mathrm{~L} \cdot \mathrm{cow} \cdot \mathrm{day}^{-1}$, respectively) strengthens this hypothesis. Another explanation of these differences in FA profile in cheese could be the presence in alpine pasture of secondary plant ingredients which may inhibit FA hydrogenation in the rumen, as hypothesized by Leiber et al. [44].

The cheese fat was significantly higher in trans-11 (+trans-10) C18:1 and CLA and lower in C16:0 with a first-use alpine or permanent grassland pasture than with a permanent grassland pasture of higher use rank (Tab. VI). Similarly, the cheese fat was significantly richer in $\beta$-carotene and xanthophylls with a first-use permanent grassland pasture than with a permanent grassland pasture of higher use rank. These results, in agreement with previous experimental findings [52], could be explained by the pattern of change of the total FA, xanthophyll and $\beta$-carotene concentrations of some plant species which are the highest in immature grass, usually during spring, and the lowest in mature grass, during the summer months $[9,21,43,53,74]$.

The basic fodder rations made up exclusively of a first-use permanent grassland pasture were associated with higher levels of CLA, trans-11 (+trans-10) C18:1, $\beta$-carotene, xanthophylls and $\alpha$-tocopherol in cheese fat than the first-use permanent grassland pasture-based rations with a hay supplementation (Tab. VI). Similar results were observed with the rations made up of second-use permanent grassland pasture for xanthophylls and $\alpha$-tocopherol. The lower supply of total FA, xanthophylls, $\beta$-carotene and $\alpha$-tocopherol by the preserved forages compared with the fresh grass probably explains these results $[9,20,33,62]$.

\subsubsection{Preserved-forage-based rations}

In the indoor feeding period, the nutritional composition of the cheese also depended on the nature of the basic fodder ration fed to the cows but in a less definite way than in the grazing period (Tab. VI). The cheeses from cows fed a maize-based ration were significantly lower in trans-11 (+trans-10) C18:1, CLA and C18:3 n-3 than those from cows fed preserved-grassbased rations. These results agree with previous findings [32, 34]. They could be explained by a higher linoleic acid content and a lower linolenic acid content in maizebased forages than in grass-based forages [55].

When the cows were fed a fodder ration rich in fermented grass, the resulting cheeses were higher in $\beta$-carotene than when cows were fed hay- or maize-based rations and in retinol than when cows were fed maizebased rations (Tab. VI). Similar findings were previously reported for the carotenoid content in milk [18, 40, 66]. A lower degradation of $\beta$-carotene in the fermented forage-making compared with the hay-making $[18,33,40]$ likely leads to a higher quantitative secretion of $\beta$-carotene into milk. Similarly, these results suggest a higher $\beta$-carotene supply by the fermented grass compared with the maize. In addition, the higher $\beta$-carotene content in fermented 
Table VII. Nutritional characteristics of cheese according to the percentage of concentrate in the pasture-based $\operatorname{diet}^{1}$.

\begin{tabular}{|c|c|c|c|c|}
\hline & \multicolumn{3}{|c|}{ Percentage of concentrate $^{2}$} & \multirow[t]{2}{*}{$P^{3}$} \\
\hline & Low & Medium & High & \\
\hline \multicolumn{5}{|l|}{ Fatty acids (\% total $\left.\mathrm{FA}^{4}\right)$} \\
\hline Total SFA ${ }^{5}$ & $66.5^{\mathrm{a}}$ & $67.7^{\mathrm{b}}$ & $68.2^{\mathrm{b}}$ & $* *$ \\
\hline $\mathrm{C} 4: 0$ & 4.14 & 4.27 & 4.17 & ns \\
\hline C6:0 & 2.55 & 2.66 & 2.61 & ns \\
\hline $\mathrm{C} 8: 0$ & 1.61 & 1.70 & 1.67 & $\mathrm{~ns}$ \\
\hline $\mathrm{C} 10: 0$ & 3.43 & 3.58 & 3.54 & $\mathrm{~ns}$ \\
\hline $\mathrm{C} 12: 0$ & 3.84 & 4.03 & 4.09 & ns \\
\hline $\mathrm{C} 14: 0$ & $12.0^{\mathrm{a}}$ & $12.3^{\mathrm{ab}}$ & $12.5^{\mathrm{b}}$ & $*$ \\
\hline C16:0 & $25.8^{\mathrm{a}}$ & $26.4^{b}$ & $26.8^{\mathrm{b}}$ & $*$ \\
\hline C18:0 & 8.73 & 8.65 & 8.58 & ns \\
\hline Total MUFA 5 & $27.4^{\mathrm{b}}$ & $26.8^{\mathrm{ab}}$ & $26.3^{\mathrm{a}}$ & $*$ \\
\hline $\mathrm{C} 18: 1 c 9$ & 18.1 & 17.9 & 17.8 & ns \\
\hline $\mathrm{C} 18: 1 t 11(+t 10)$ & $3.16^{\mathrm{b}}$ & $2.60^{\mathrm{a}}$ & $2.49^{\mathrm{a}}$ & $* * *$ \\
\hline Total PUFA 5 & $4.82^{\mathrm{b}}$ & $4.18^{\mathrm{a}}$ & $4.26^{\mathrm{a}}$ & $* * *$ \\
\hline C18:2 (n-6) & $1.59^{\mathrm{b}}$ & $1.43^{\mathrm{a}}$ & $1.46^{\mathrm{a}}$ & $*$ \\
\hline $\mathrm{C} 18: 2 c 9 t 11\left(\mathrm{CLA}^{5}\right)$ & $1.36^{\mathrm{b}}$ & $1.10^{\mathrm{a}}$ & $1.06^{\mathrm{a}}$ & $* * *$ \\
\hline C18:3 (n-3) & $0.89^{b}$ & $0.77^{\mathrm{a}}$ & $0.81^{\mathrm{a}}$ & $* * *$ \\
\hline $\mathrm{C} 12: 0+\mathrm{C} 14: 0+\mathrm{C} 16: 0^{6}$ & $41.6^{\mathrm{a}}$ & $42.7^{b}$ & $43.3^{\mathrm{b}}$ & $* *$ \\
\hline Total trans $\mathrm{FA}^{5,7}$ & $5.55^{\mathrm{b}}$ & $4.76^{\mathrm{a}}$ & $4.58^{\mathrm{a}}$ & $* * *$ \\
\hline \multicolumn{5}{|l|}{ Vitamins and carotenoids } \\
\hline$\beta$-Carotene $\left(\mathrm{mg} \cdot \mathrm{kg}^{-1}\right.$ fat $)$ & 4.83 & 4.81 & 4.39 & ns \\
\hline Xanthophylls (mg $\cdot \mathrm{kg}^{-1}$ fat) & $0.35^{\mathrm{b}}$ & $0.32^{\mathrm{b}}$ & $0.27^{\mathrm{a}}$ & $* * *$ \\
\hline Retinol (mg.kg ${ }^{-1}$ fat) & $5.76^{\mathrm{b}}$ & $5.69^{\mathrm{b}}$ & $5.26^{\mathrm{a}}$ & $*$ \\
\hline$\alpha$-Tocopherol (mg $\cdot \mathrm{kg}^{-1}$ fat $)$ & 7.53 & 7.90 & 7.02 & $\mathrm{~ns}$ \\
\hline $\mathbf{T A C}\left(\mathrm{mol} \mathrm{Fe}{ }^{2+} \cdot \mathrm{kg}^{-1} \mathrm{DM}\right)^{8}$ & 14.8 & 14.9 & 14.6 & ns \\
\hline
\end{tabular}

${ }^{1}$ Values indicated are least-square means. ${ }^{2}$ Low: $15 \%$; Medium: 26\%; High: $41 \%$ (in the total diet). ${ }^{3}$ Significance of the effect of the percentage of concentrate in the herd diet; ns: not significant; $* P<$ 0.05 ; ** $P<0.01$; *** $P<0.001$. 4 Total FA: total fatty acids. 5 SFA: saturated fatty acids; MUFA: monounsaturated fatty acids; PUFA: polyunsaturated fatty acids; CLA: conjugated linoleic acid; trans FA: trans fatty acids. 6 Potentially hypercholesterolemic saturated fatty acids [31]. ${ }^{7} \Sigma$ (trans-C16:1; trans-C18:1; cis, trans-C18:2; trans, cis-C18:2; trans, trans-C18:2; trans-C20:1 without trans-CLA). 8 TAC: total antioxidant capacity; DM: dry matter. a,b,c Values without a common letter differ significantly $(P<0.05)$ in the same row.

grass probably explains the higher TAC in cheese associated with the fodder rations rich in fermented forages (Tab. VI).

\subsubsection{Nature and percentage of concentrate}

The percentage of concentrate in the herd diet had a significant effect on the cheese composition only when cows were fed pasture-based rations. In this case, as the percentage of concentrate fed to the cows was lower, hence that of green grass was higher, the cheese fat was poorer in C14:0 and $\mathrm{C} 16: 0$ and richer in trans-11 (+trans-10) C18:1, CLA, C18:2 n-6, C18:3 n-3, xanthophylls and retinol (Tab. VII). These results 
agree with previous findings for the FA [22, 69]. They suggest that there were higher FA and carotenoid contents and/or bioavailability in the green grass than in the concentrates.

The level of fat from the concentrates fed to the cows significantly influenced only the $\mathrm{C} 18: 2 \mathrm{n}-6$ percentage in cheese. The cheese fat was so rich in C18:2 n-6 that the percentage of fat from the concentrates in the herd diet was high in both the grazing period and the indoor feeding period. Thus, the C18:2 n-6 percentage increased from $1.37 \%$ total FA in the grazing period and from $1.26 \%$ total $\mathrm{FA}$ in the winter period with the low percentage of fat from the concentrates to $1.63 \%$ total FA in both the grazing period and the winter period with the high percentage of fat from the concentrates. The FA profile of concentrates probably explains this effect. Linoleic acid is the predominant FA in the fat of cereal and oilseed fat [55]. Consequently, a higher intake of fat from concentrate probably brings about a higher secretion of linoleic acid into milk, as previously shown experimentally [13].

\subsubsection{Vitamin supplementation}

The vitamin supplementation of the pasture-based rations had no significant effect on the retinol and $\alpha$-tocopherol contents in the cheese (Fig. 2). On the other hand, when cows were fed a preserved-forage-based ration, the retinol content in cheese fat was increased in a dose-dependent way by the vitamin A supplementation (Fig. 2). Similarly, the $\alpha$-tocopherol content in cheese fat was positively influenced by the vitamin $\mathrm{E}$ supplementation of the preserved-foragebased rations, but only with the high level of supplementation. These results agree with previous experimental findings related to milk [26, 29, 57, 70]. The retinol and $\alpha$-tocopherol contents in milk fat directly depend on their level in the cow's diet, but also on that of $\beta$-carotene for retinol [29]. The secretion of retinol and $\alpha$-tocopherol from plasma into milk is, however, limited in quantity [37, 72]. Consequently, the plasma retinol and $\alpha$-tocopherol levels could be in every case beyond the maximal secretory capacity of these vitamins from
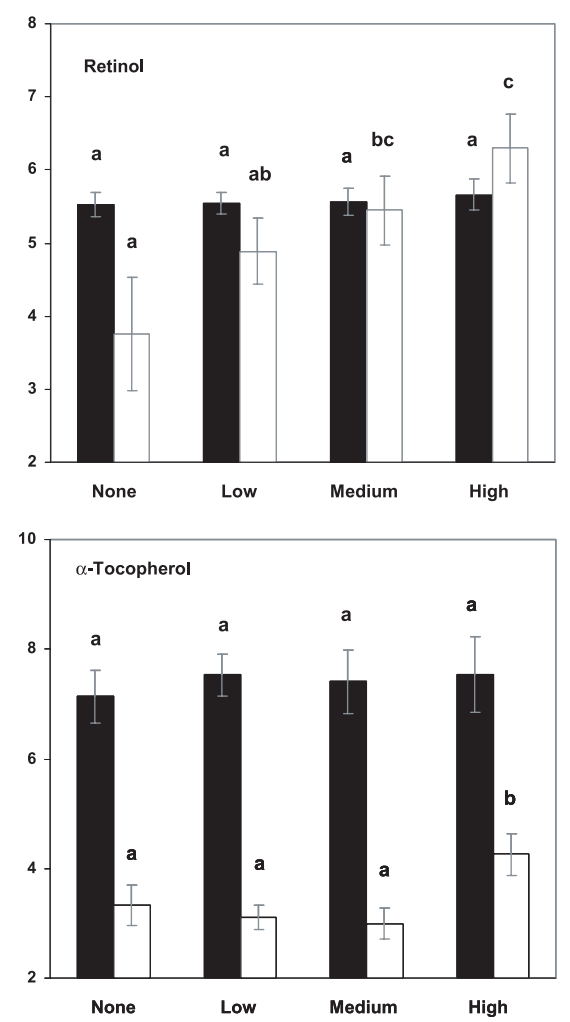

Figure 2. Retinol and $\alpha$-tocopherol contents in cheese for none, low, medium and high levels of vitamin supplementation of the cow's diet with pasture-based rations ( $\boldsymbol{\square}$ ) and preservedforage-based rations $(\square)$. Results are expressed as $\mu \mathrm{g} . \mathrm{g}^{-1}$ fat. ${ }^{\mathrm{a}, \mathrm{b}, \mathrm{c}}$ Values without a common letter differ significantly $(P<0.05)$ within pasturebased rations and within hay-based rations.

plasma into milk with the pasture-based rations, due to the richness in $\beta$-carotene and $\alpha$-tocopherol of the green grass, but not with the rations based on preserved forages which are poorer in these micronutrients $[33,62]$.

\subsubsection{Genetic and physiological factors}

The physiological and genetic factors influenced the composition of the cheese much less than the nutritional factors (Tab. V). In every case, the percentage of 
primiparous in the herd did not significantly influence the FA profile and the micronutrient contents in the cheese in either the grazing period or the indoor feeding period. These results agree with previous findings which have shown that the cow's parity have only a very little effect on the FA profile of milk fat [39]. In addition, although the percentage of several FA was significantly influenced by the stage of lactation and the milk yield of the herd (Tab. V), these effects were very low and not consistent between the grazing period and the indoor feeding period, suggesting they were possibly due to residual or unmeasured confounding effects. These results differ from previous experimental findings which have shown the strong influence of the lactation stage of cows on the FA, vitamin and carotenoid composition of milk $[13,29,37]$. A too dispersed a calving distribution has probably restricted the influence of lactation stage in this study.

The breed of the herd was associated with more significant differences in the FA profile of the cheese (Tab. VIII). However, this effect was not corroborated between the grazing period and the indoor feeding period, suggesting it was possibly due to residual or unmeasured confounding effects of nutritional factors in particular. Previous studies have already reported differences in milk FA profile between cow breeds [39, 42]. The influence of a cow's breed on the milk FA profile could in part be explained by differences between breeds in the activity of the mammary enzyme stearoyl coenzyme A desaturase which oxidizes $\mathrm{C} 16: 0$ to C16:1 and C18:0 to C18:1 and is involved in CLA production [54]. The differences between breeds of activity of this enzyme can be assessed by calculating desaturase indexes from the products and the substrates of this enzyme (Tab. VIII). It appears clearly that the CLA-desaturase index was higher for the Abondance and Montbéliarde breeds than for the Holstein breed with both the pasture-based rations and the preservedforage-based rations. That could partly explain the lower CLA percentage in cheese fat from the Holstein breed. The higher percentage of CLA with the Montbéliarde breed compared with the Holstein breed agrees with the findings of Lawless et al. [42]. On the other hand, the differences between breeds of desaturase indexes for cis-9 C16:1 and cis-9 C18:1 were inconsistent between the grazing period and the indoor feeding period, in particular concerning the desaturase indexes of the Abondance breed, which were the highest with the pasture-based rations but not with the preserved-forage-based rations. That strengthens the hypothesis of confounding effects of nutritional factors. The alpine pasture management of a great part of the Abondance herds could have caused a body fat mobilization, as previously suggested, and therefore a higher transfer from the blood into milk of cis-9 C16:1 and cis-9 C18:1, preferentially present in adipose tissue [13], resulting in higher apparent desaturase indexes.

On the other hand, the herd breed similarly influenced the carotenoid content in cheese fat in the grazing period and in the indoor feeding period, but only in a significant way with the pasture-based rations (Fig. 3). The xanthophyll and $\beta$-carotene contents in cheese fat were the richest with the Montbéliarde breed and the poorest with the Abondance breed, respectively. Several studies have previously observed an effect of the cow's breed on the carotenoid content in milk fat $[29,41,65,71]$, but none have experimentally compared these three breeds to our knowledge. The variations in the carotenoid content in milk fat related to the cow's breed could be due to differences between breeds of: (1) intestinal conversion of $\beta$-carotene into retinal by the 15,15 ' dioxygenase [29], (2) quantitative secretion of $\beta$-carotene from plasma into milk [37] and/or (3) $\beta$-carotene storage and mobilization [67]. The differences between breeds of activity of $15,15^{\prime}$ dioxygenase can be assessed by calculating the retinol: $\beta$-carotene ratio (Fig. 3). The Montbéliarde breed and the Abondance breed were, respectively, associated with the lowest and the highest retinol: $\beta$-carotene ratio and therefore cleavage activity of 15,15 ' dioxygenase both with the pasture and the indoor feeding. This result suggests that the differences in $\beta$-carotene content in cheese fat between breeds were strongly due to 


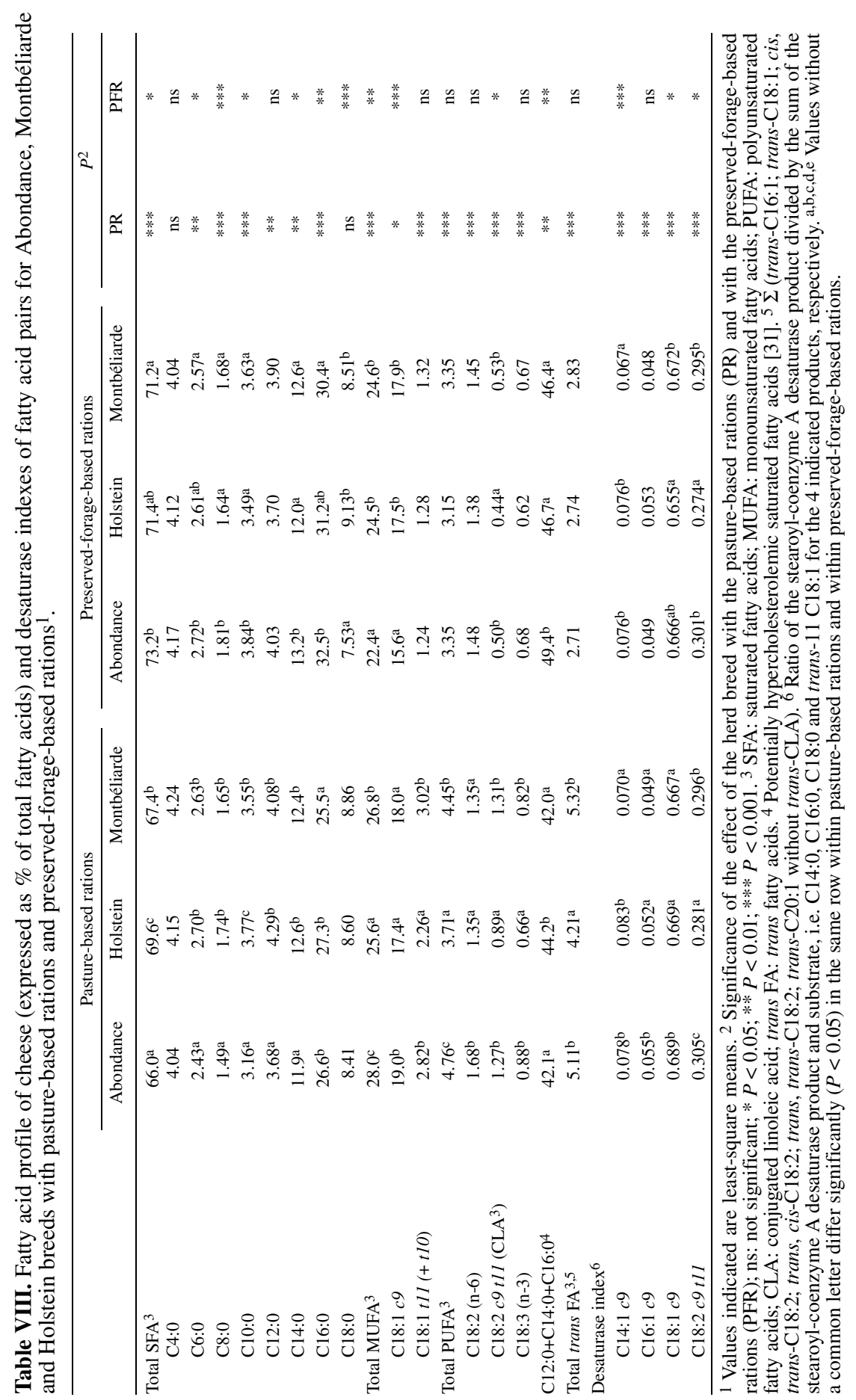



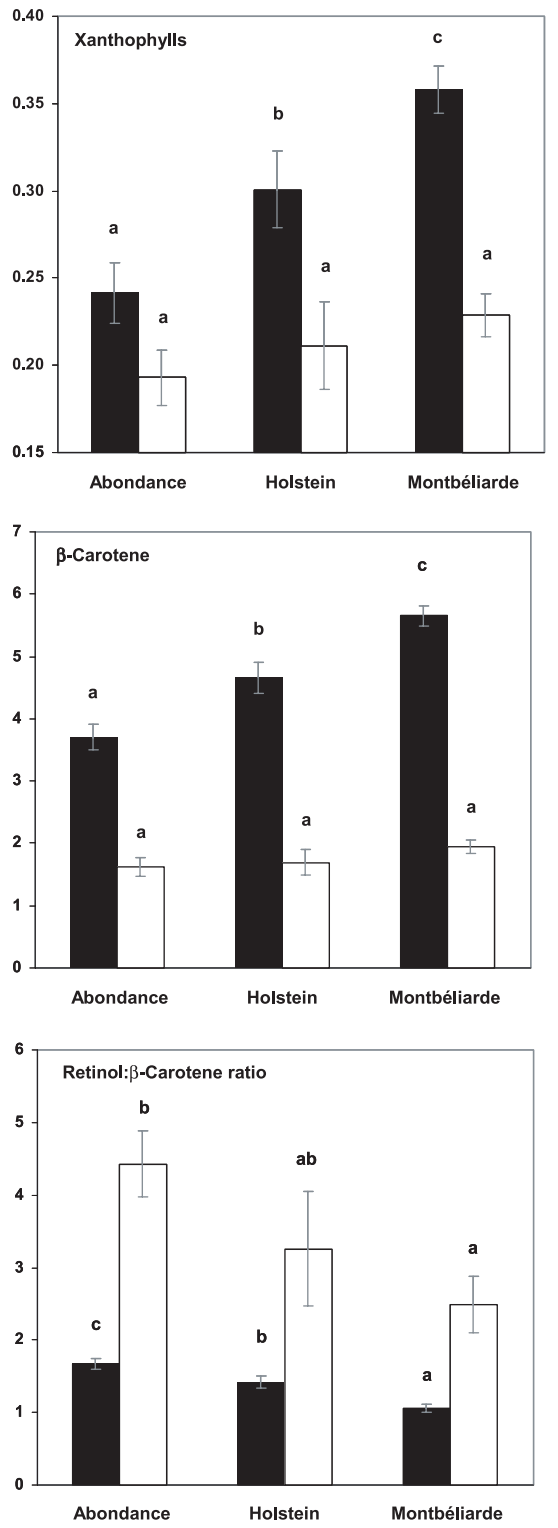

Figure 3. Xanthophyll and $\beta$-carotene contents and retinol: $\beta$-carotene ratio in cheese for Abondance, Holstein and Montbéliarde breeds with pasture-based rations (ם) and preserved-forage-based rations $(\square)$. Results are expressed as $\mu \mathrm{g} \cdot \mathrm{g}^{-1}$ fat for xanthophyll and $\beta$-carotene contents. a,b,c Values without a common letter differ significantly $(P<0.05)$ within pasture-based rations and within hay-based rations. differences in cleavage activity of 15,15 , dioxygenase to convert $\beta$-carotene into retinal. In addition, the lower retinol: $\beta$-carotene ratio with the pasture-based rations compared with the preserved-forage-based rations (Fig. 3) confirmed that the 15, 15' dioxygenase displays Michaelis-Menten type kinetics [73]. Indeed, the activity of this enzyme is higher when a lower $\beta$-carotene concentration is present, i.e. with the preserved-forage rations.

\section{CONCLUSION}

To our knowledge, the present study is the first which attempts to explain the variations in the nutritional composition of cheeses produced under real conditions of production by considering so many cheese samples. It showed that there is a high variability in composition in farmhouse pressed cheeses and interdependence between the fat-soluble components. It is particularly interesting to note that the carotenoid, retinol and $\alpha$-tocopherol contents and the FA profile in cheese simultaneously varied in a nutritionally favorable way. Within the studied range of conditions of milk production, the FA profile and the retinol, $\alpha$-tocopherol and carotenoid contents in cow's milk cheese strongly depend on the cow's diet, in particular the level of pasture. It appears, however, that other management practices (vitamin supplementation and herd breed) could also have appreciable effects on the cheese nutritional characteristics. The correlational approach used in this study involves being cautious in the interpretation of the results insofar as correlations do not necessarily imply cause and effect relationships between variables. The strong associations between the preservation mode of forages and the nutritional characteristics of cheese can, however, be considered to be cause and effect relationships because they confirmed experimental findings. On the other hand, owing to potential confounding effects inherent in this type of study, some aspects need to be validated in experimental conditions such as the effects of the maturity stage of grass, the nature of grassland and the cow's breed. 
Moreover, a better knowledge of the doseresponse relationship between the level of vitamin supplementation of a cow's diet and the retinol and $\alpha$-tocopherol contents in milk fat could allow a better control of the levels of these vitamins in dairy products, in particular when cows are fed indoor rations.

Acknowledgements: This work was carried out within the framework of the programs of research and development of the Groupement d'Intérêt Scientifique des Alpes du Nord (Chambéry, France) and Pôle Fromager AOC Massif Central (Aurillac, France). We thank the Comité Interprofessionnel des Fromages du Cantal (Aurillac, France), Syndicat Interprofessionnel du Fromage d'Abondance (Thonon-lesBains, France) and Syndicat Interprofessionnel de la Tomme de Savoie (Annecy, France) for their contribution to this study. The authors thank the Association Nationale de la Recherche Technique for financial support. We are grateful to R. Lavigne from the Unité de Recherches Fromagères (INRA, Aurillac, France), Dr. G. Potier de Courcy from the Institut Scientifique et Technique de la Nutrition et de l'Alimentation (Paris, France), P. Capitan from the Unité de Recherches sur les Herbivores (INRA, Clermont-Ferrand, France), B. Lyan, J.-C. Tressol and C. Lab from the Unité de Maladies Métaboliques et de Micronutriments (INRA, Clermont-Ferrand, France) for technical assistance with manufacturing Cantal-type cheeses, the microbiological assay used to determine folate content, determination of fatty acid profiles, fat-soluble vitamin and carotenoid analysis, mineral analysis and the total antioxidant capacity assay, respectively. We also acknowledge C. Journal and C. Sibra from the École Nationale d'Ingénieurs des Travaux Agricoles (ClermontFerrand, France) for their great help with data analysis.

\section{REFERENCES}

[1] AFNOR, Fromage. Détermination de la matière sèche (méthode par étuvage). Norme NF V04-282, in: Recueil de normes françaises. Laits et produits laitiers. Méthodes d'analyse, Agence Française de Normalisation, Paris, France, 1980.

[2] AFNOR, Fromage. Détermination de la teneur en phosphate total. Méthode par spectrométrie d'absorption moléculaire. Norme
NF V04-284, in: Recueil de normes françaises. Laits et produits laitiers. Méthodes d'analyse, Agence Française de Normalisation, Paris, France, 1985.

[3] AFSSA, Rapport du groupe de travail sur le sel, Agence Française de Sécurité Sanitaire des Aliments, Maisons-Alfort, France, 2002.

[4] AFSSA, Risque et bénéfices pour la santé des acides gras trans apportés par les aliments, Agence Française de Sécurité Sanitaire des Aliments, Maisons-Alfort, France, 2005.

[5] Agabriel C., Ferlay A., Journal C., Sibra C., Teissier D., Grolier P., Bonnefoy J.-C., Rock E., Chilliard Y., Martin B., Composés d'intérêt nutritionnel de laits de grand mélange : teneurs en acides gras et vitamines selon l'altitude et la saison, in: Proc. 11 ${ }^{\mathrm{e}}$ Rencontres Rech. Rumin., Paris, France, 8-9 December 2004, pp. 51-54.

[6] Aro A., Antoine J.M., Pizzoferrato L., Reykdal O., van Poppel G., Trans fatty acids in dairy and meat products from 14 European countries: the TRANSFAIR study, J. Food Comp. Anal. 11 (1998) 150-160.

[7] Benzie I.F.F., Strain J.J., The ferric reducing ability of plasma (FRAP) as a measure of "antioxidant power": the FRAP assay, Anal. Biochem. 239 (1996) 70-76.

[8] Bossart M.A., Leuenberger H., Kuenzi N., Blum J.W., Levels of hormones and metabolites, insulin responses to glucose infusions, glucose tolerances and growth rates in different breeds of steers: studies during and after an alpine sojourn, Z. Tierzüchtg. Züchtgsbiol. 102 (1985) 23-33.

[9] Boufaïed H., Chouinard P.Y., Tremblay G.F., Petit H.V., Michaud R., Bélanger G., Fatty acids in forages. I. Factors affecting concentrations, Can. J. Anim. Sci. 63 (2003) 501-511.

[10] Bugaud C., Bornard A., Hauwuy A., Martin B., Salmon J.C., Tessier L., Buchin S., Relation entre la composition botanique de végétations de montagne et leur composition en composés volatils, Fourrages 162 (2000) 141-155.

[11] Bugaud C., Buchin S., Coulon J.B., Hauwuy A., Dupont D., Influence of the nature of alpine pastures on plasmin activity, fatty acid and volatile compound composition of milk, Lait 81 (2001) 401-414.

[12] Centre National Interprofessionnel de l'Économie Laitière, Banque de données statistiques, http://www.cniel.com, 2005.

[13] Chilliard Y., Ferlay A., Mansbridge R.M., Doreau M., Ruminant milk fat plasticity: nutritional control of saturated, polyunsaturated, trans and conjugated fatty acids, Ann. Zootech. 49 (2000) 181-205. 
[14] Chilliard Y., Ferlay A., Doreau M., Effect of different types of forages, animal fat or marine oils in cow's diet on milk fat secretion and composition, especially conjugated linoleic acid (CLA) and polyunsaturated fatty acids, Livest. Prod. Sci. 70 (2001) 31-48.

[15] Christidès J.P., Potier de Courcy G., Teneur en acide folique des aliments. 2. Optimisation du dosage microbiologique des folates dans les aliments, Sci. Aliments 7 (1987) 7-22.

[16] Clifton P.M., Keogh J.B., Noakes M., Trans fatty acids in adipose tissue and the food supply are associated with myocardial infarction, J. Nutr. 134 (2004) 874-879.

[17] Collomb M., Bütikofer U., Sieber R., Bosset J.O., Jeangros B., Conjugated linoleic acid and trans fatty acid composition of cows' milk fat produced in lowlands and highlands, J. Dairy Res. 68 (2001) 519-523.

[18] Coulon J.B., Priolo A., La qualité sensorielle des produits laitiers et de la viande dépend des fourrages consommés par les animaux, Prod. Anim. 15 (2002) 333-342.

[19] Debry G., Lait, nutrition et santé, Lavoisier, Paris, France, 2001.

[20] Dewhurst R.J., King P.J., Effects of extended wilting, shading and chemical additives on the fatty acids in laboratory grass silages, Grass Forage Sci. 53 (1998) 219-224.

[21] Dewhurst R.J., Scollan N.D., Youell S.J., Tweed J.K.S., Humphreys M.O., Influence of species, cutting date and cutting interval on the fatty acid composition of grasses, Grass Forage Sci. 56 (2001) 68-74.

[22] Dhiman T.R., Anand G.R., Satter L.D., Pariza M.W., Conjugated linoleic acid content of milk from cows fed different diets, J. Dairy Sci. 82 (1999) 2146-2156.

[23] Dohoo I.R., Ducrot C., Fourichon C., Donald A., Hurnik D., An overview of techniques for dealing with large numbers of independent variables in epidemiologic studies, Prev. Vet. Med. 29 (1996) 221-239.

[24] Forssén K.M., Jägerstad M.I., Wigertz K., Witthöft C.M., Folates and dairy products: a critical update, J. Am. Coll. Nutr. 19 (2000) 100S-110S.

[25] Fox P.F., Cheese: chemistry, physics and microbiology, Vol. 2, Major cheese groups, Chapman \& Hall, London, UK, 1993.

[26] Gaivoronskii I., Chestyunina V., Effect of vitamin A supplementation on composition of colostrum and milk of cows, Molochnoe Myasnoe Skotovod. 9 (1984) 18-20.

[27] Greenfield H., Southgate D.A.T., Food composition data - Production, management and use, Food and Agriculture Organization of the United Nations, Rome, Italy, 2003.
[28] Guéguen L., La composition minérale du lait et son adaptation aux besoins minéraux du jeune, Ann. Nutr. Alim. 24 (1971) A335A381.

[29] Hartman A.M., Dryden L.P., Vitamins in milk and milk products, American Dairy Science Association, USA, 1965.

[30] Heiss E., Essai de dosage de la matière grasse dans les fromages par des méthodes rapides, Dtsch. Molk. Zeit. 82 (1961) 67-70.

[31] Hu F.B., Manson J.E., Willett W.C., Types of dietary fat and risk of coronary heart disease: a critical review, J. Am. Coll. Nutr. 20 (2001) 5-19.

[32] Hurtaud C., Delaby L., Peyraud J.L., The nature of conserved forage affects milk composition and butter properties, in: Proc. 19th Gen. Meet. Eur. Grassl. Fed., La Rochelle, France, 2002, pp. 576-577.

[33] Iwanska S., Pysera B., Strusinska D., Carotenoids content of green forages and preserved feeds, Acta Acad. Agricult. Techn. Olst. Zootech. 47 (1997) 117-128.

[34] Jahreis G., Fritsche J., Steinhart H., Conjugated linoleic acid in milk fat: high variation depending on production system, Nutr. Res. 17 (1997) 1479-1484.

[35] Jeangros B., Scehovic J., Troxler J., Bachmann H.J., Bosset J.O., Comparaison de caractéristiques botaniques et chimiques d'herbages pâturés en plaine et en montagne, Fourrages 159 (1999) 277-292.

[36] Jenness R., Composition and characteristics of goat milk: review 1968-1979, J. Dairy Sci. 63 (1980) 1605-1630.

[37] Jensen S.K., Johannsen A.K.B., Hermansen J.E., Quantitative secretion and maximal secretion capacity of retinol, $\beta$-carotene and $\alpha$-tocopherol into cows' milk, J. Dairy Res. 66 (1999) 511-522.

[38] Kalač P., Losses of beta-carotene in unwilted forage crops during silage-making and feeding, Anim. Feed Sci. Technol. 9 (1983) 63-69.

[39] Kelsey J.A., Corl B.A., Collier R.J., Bauman D.E., The effect of breed, parity and stage of lactation on conjugated linoleic acid (CLA) in milk fat from dairy cows, J. Dairy Sci. 86 (2003) 2588-2597.

[40] Krukovsky V.N., Trimberger G.W., Turk K.L., Loosli J.K., Henderson C.R., Influence of roughages on certain biochemical properties of milk, J. Dairy Sci. 37 (1954) 1-9.

[41] Krukovsky V.N., Whiting F., Loosli J.K., Tocopherol, carotenoid and vitamin A content of milk fat and the resistance of milk to the development of oxidized flavors as influenced by breed and season, J. Dairy Sci. 33 (1950) 791-796. 
[42] Lawless F., Stanton C., L'Escop P., Devery R., Dillon P., Murphy J.J., Influence of breed on bovine milk cis-9, trans-11-conjugated linoleic acid content, Livest. Prod. Sci. 62 (1999) 43-49.

[43] Layug D.V., Ohshima M., Yokota H., Nagatomo T., Ostrowski-Meissner H.T., Effect of maturity stage on the protein and carotenoid yields of alfalfa leaf extract and press cake, Grassl. Sci. 41 (1996) 287-293.

[44] Leiber F., Kreuzer M., Nigg D., Wettstein H.R., Scheeder M.R.L., A study on the causes for the elevated n-3 fatty acids in cows' milk of alpine origin, Lipids 40 (2005) 191-2002.

[45] Loor J.J., Ferlay A., Ollier A., Doreau M., Chilliard Y., Relationship among trans and conjugated fatty acids and bovine milk fat yield due to dietary concentrate and linseed oil, J. Dairy Sci. 88 (2005) 726-740.

[46] Lopez H.W., Duclos V., Coudray C., Krespine V., Feillet-Coudray C., Messager A., Demigné C., Rémésy C., Making bread with sourdough improves mineral bioavailability from reconstituted whole wheat flour in rats, Nutr. 19 (2003) 524-530.

[47] Lucas A., Coulon J.B., Grolier P., Martin B., Rock E., Nutritional quality of dairy products and human health, in: Hocquette J.F., Gigli S. (Eds.), Indicators of milk and beef quality, Wageningen Academic Publishers, Wageningen, The Netherlands, 2005, pp. 163-178.

[48] Lucas A., Rock E., Chamba J.F., VerdierMetz I., Brachet P., Coulon J.B., Respective effects of milk composition and the cheesemaking process on cheese compositional variability in components of nutritional interest, Lait 86 (2006) 21-41.

[49] Lucey J.A., Fox P.F., Importance of calcium and phosphate in cheese manufacture: a review, J. Dairy Sci. 76 (1993) 1714-1724.

[50] Lyan B., Azais-Braesco V., Cardinault N., Tyssandier V., Borel P., Alexandre-Gouabau M.C., Grolier P., Simple method for clinical determination of 13 carotenoids in human plasma using an isocratic high-performance liquid chromatographic method, J. Chromatogr. B Biomed. Sci. Appl. 751 (2001) 297-303.

[51] Martin A., Apports nutritionnels conseillés pour la population française, Lavoisier, Paris, France, 2001, 605 p.

[52] Martin B., Ferlay A., Pradel P., RockE., Grolier P., Dupont D., Gruffat D., Besle J.M., Ballot N., Chilliard Y., Coulon J.B., Variabilité de la teneur des laits en constituants d'intérêt nutritionnel selon la nature des fourrages consommés par les vaches laitières, in: Proc. 9e Rencontres Rech. Rumin., Paris, France, 4-5 Décembre 2002, pp. 347-350.
[53] McDowall F.H., McGillivray W.A., Studies on the properties of New Zealand butterfat. VII. Effect of stage of maturity of ryegrass fed to cows on the characteristics of butterfat and its carotene and vitamin A contents, J. Dairy Res. 30 (1963) 59-66.

[54] Medrano J.F., Johnson A., De Peters E.J., Islas A., Genetic modification of the composition of milk fat : identification of polymorphisms within the bovine stearoyl-Co-Adesaturase gene, J. Dairy Sci. 82 (1999) 71.

[55] Morand-Fehr P., Tran G., La fraction lipidique des aliments et les corps gras utilisés en alimentation animale, Prod. Anim. 14 (2001) 285-302.

[56] Ndaw S., Bergaentzle M., Aoude-Werner D., Lahely S., Hasselmann C., Determination of folates in foods by high-performance liquid chromatography with fluorescence detection after precolumn conversion to 5-methyltetrahydrofolates, J. Chromatogr. A. 928 (2001) 77-90.

[57] Nicholson J.W.G., St-Laurent A.-M., Effect of forage type and supplemental dietary vitamin E on milk oxidative stability, Can. J. Anim. 71 (1991) 1181-1186.

[58] Nowson C.A., Morgan T.O., Gibbons C., Decreasing dietary sodium while following a self-selected potassium-rich diet reduces blood pressure, J. Nutr. 133 (2003) 4118-4123.

[59] Palmquist D.L., Beaulieu A.D., Feed and animal factors influencing milk fat composition, J. Dairy Sci. 76 (1993) 1753-1771.

[60] Park Y.W., Anderson M.J., Walters J.L., Mahoney A.W., Effects of processing methods and agronomic variables on carotene contents in forages and predicting carotene in alfalfa hay with near-infrared-reflectance spectroscopy, J. Dairy Sci. 66 (1983) 235-245.

[61] Reif G.D., Shahani K.M., Vakil J.R., Crowe L.K., Factors affecting B-complex vitamin content of Cottage cheese, J. Dairy Sci. 59 (1976) 410-415.

[62] Robowsky K.D., Knabe O., Investigations on the alpha-tocopherol content of fodder grasses. 3. Influence of conservation and storage on the alpha -tocopherol content of fodder grasses, Arch. Tierernahr. 22 (1972) 125-132.

[63] Ruhland K., Gränzer W., Groth W., Pirchner F., Blood levels of hormones and metabolites, erythrocytes and leukocytes and respiration and pulse rate of heifers after alpage, J. Anim. Breed. Genet. 116 (1999) 415-423.

[64] Sanchez-Villegas A., Martinez J.A., Prattala R., Toledo E., Roos G., Martinez-Gonzalez M.A., A systematic review of socioeconomic differences in food habits in Europe: consumption of cheese and milk, Eur. J. Clin. Nutr. 57 (2003) 917-929. 
[65] Scott K.J., Bishop D.R., Zechalko A., Edwards-Webb J.D., Nutrient content of liquid milk. I. Vitamins $\mathrm{A}, \mathrm{D}_{3}, \mathrm{C}$ and of the B complex in pasteurized bulk liquid milk, J. Dairy Res. 51 (1984) 37-50.

[66] Shingfield K.J., Salo-Väänänen P., Pahkala E., Toivonen V., Jaakkola S., Piironen V., Huhtanen P., Effect of forage conservation method, concentrate level and propylene glycol on the fatty acid composition and vitamin content of cows' milk, J. Dairy Res. 72 (2005) 349-361.

[67] Siebert B.D., Pitchford W.S., Kruk Z.A. Kuchel H., Deland M.P.B., Bottema C.D.K., Differences in $\Delta^{9}$ desaturase activity between Jersey- and Limousine-sired cattle, Lipids 38 (2003) 539-543.

[68] Smit L.E., Schönfeldt H.C., de Beer W.H.J., Smith M.F., The influence of factory and region on the composition of South African cheddar and gouda cheese, J. Food Comp. Anal. 14 (2001) 177-198.

[69] Stockdale C.R., Walker G.P., Wales W.J., Dalley D.E., Birkett A., Shen Z., Doyle P.T., Influence of pasture and concentrates in the diet of grazing dairy cows on the fatty acid composition of milk, J. Dairy Res. 70 (2003) 267-276.
[70] Strusinska D., Mierzejewska J., Skok A., Concentration of mineral components, betacarotene, vitamins $\mathrm{A}$ and $\mathrm{E}$ in cow colostrum and milk when using mineral-vitamin supplements, Med. Weter. 60 (2004) 202-206.

[71] Thompson S.Y., Henry K.M., Kon S.K., Factors affecting the concentration of vitamins in milk. I. Effect of breed, season and geographical location on fat-soluble vitamins, J. Dairy Res. 31 (1964) 1-25.

[72] Tomlinson J.E., Mitchell G.E., Bradley N.W., Tucker R.E., Boling J.A., Schelling G.T., Transfer of vitamin A from bovine liver to milk, J. Anim. Sci. 39 (1974) 813-817.

[73] Yang A., Tume R.K., A comparison of $\beta$-carotene-splitting activity isolated from intestinal mucosa of pasture-grazed sheep, goats and cattle, Biochem. Mol. Biol. Int. 30 (1993) 209-217.

[74] Yoo S.D., Greer D.H., Laing W.A., McManus M.T., Changes in photosynthetic efficiency and carotenoid composition in leaves of white clover at different developmental stages, Plant Physiol. Biochem. 41 (2003) 887-893. 